OPEN ACCESS

Edited by:

Daniel McVicar,

National Cancer Institute (NCl),

United States

Reviewed by:

Yasumasa Kato,

Ohu University, Japan

Cinzia Antognelli,

University of Perugia, Italy

*Correspondence:

Stine F. Pedersen

sfpedersen@bio.ku.dk

Specialty section: This article was submitted to

Cancer Metabolism,

a section of the journa

Frontiers in Oncology

Received: 01 December 2019

Accepted: 14 April 2020

Published: 07 May 2020

Citation:

Malinda RR, Zeeberg K, Sharku PC,

Ludwig MQ, Pedersen LB,

Christensen ST and Pedersen SF

(2020) TGF $\beta$ Signaling Increases Net

Acid Extrusion, Proliferation and

Invasion in Panc-1 Pancreatic Cancer

Cells: SMAD4 Dependence and Link

to Merlin/NF2 Signaling.

Front. Oncol. 10:687.

doi: 10.3389/fonc.2020.00687

\section{TGF $\beta$ Signaling Increases Net Acid Extrusion, Proliferation and Invasion in Panc-1 Pancreatic Cancer Cells: SMAD4 Dependence and Link to Merlin/NF2 Signaling}

Raj R. Malinda, Katrine Zeeberg, Patricia C. Sharku, Mette Q. Ludwig, Lotte B. Pedersen, Søren T. Christensen and Stine F. Pedersen*

Section for Cell Biology and Physiology, Department of Biology, Faculty of Science, University of Copenhagen, Copenhagen, Denmark

Pancreatic ductal adenocarcinoma (PDAC) is a major cause of cancer-related death, with a 5 -year survival of $<10 \%$ and severely limited treatment options. PDAC hallmarks include profound metabolic acid production and aggressive local proliferation and invasiveness. This phenotype is supported by upregulated net acid extrusion and epithelial-to-mesenchymal transition (EMT), the latter typically induced by aberrant transforming growth factor- $\beta$ (TGF $\beta$ ) signaling. It is, however, unknown whether TGF $\beta$-induced EMT and upregulation of acid extrusion are causally related. Here, we show that mRNA and protein expression of the net acid extruding transporters $\mathrm{Na}^{+} / \mathrm{H}^{+}$ exchanger 1 ( $\mathrm{NHE1}$, SLC9A1) and $\mathrm{Na}^{+}, \mathrm{HCO}_{3}^{-}$cotransporter 1 (NBCn1, SLC4A7) are increased in a panel of human PDAC cell lines compared to immortalized human pancreatic ductal epithelial (HPDE) cells. Treatment of Panc-1 cells (which express SMAD4, required for canonical TGF $\beta$ signaling) with TGF $\beta-1$ for $48 \mathrm{~h}$ elicited classical EMT with down- and upregulation of epithelial and mesenchymal markers, respectively, in a manner inhibited by SMAD4 knockdown. Accordingly, less pronounced EMT was induced in BxPC-3 cells, which do not express SMAD4. TGF $\beta-1$ treatment elicited a SMAD4-dependent increase in NHE1 expression, and a smaller, SMAD4-independent increase in NBCn1 in Panc-1 cells. Consistent with this, TGF $\beta-1$ treatment led to elevated intracellular $\mathrm{pH}$ and increased net acid extrusion capacity in Panc-1 cells, but not in BxPC-3 cells, in an NHE1-dependent manner. Proliferation was increased in Panc- 1 cells and decreased in BxPC-3 cells, upon TGF $\beta-1$ treatment, and this, as well as EMT per se, was unaffected by NHE1- or NBCn1 inhibition. TGF $\beta$-1-induced EMT was associated with a 4-fold increase in Panc-1 cell invasiveness, which further increased $\sim 10$-fold upon knockdown of the tumor suppressor Merlin (Neurofibromatosis type 2). Knockdown of NHE1 or NBCn1 abolished Merlin-induced invasiveness, but not that induced by TGF $\beta-1$ alone. In conclusion, NHE1 and NBCn1 expression and NHE-dependent acid extrusion are upregulated during TGF $\beta$-1-induced EMT of Panc-1 
cells. NHE1 upregulation is SMAD4-dependent, and SMAD4-deficient BxPC-3 cells show no change in $\mathrm{pH}_{\mathrm{i}}$ regulation. $\mathrm{NHE1}$ and $\mathrm{NBCn} 1$ are not required for EMT per se or EMT-associated proliferation changes, but are essential for the potentiation of invasiveness induced by Merlin knockdown.

Keywords: NHE1, SLC9A1, NBCn1, SLC4A7, Merlin, proliferation, invasion, PDAC

\section{INTRODUCTION}

Pancreatic ductal adenocarcinoma (PDAC) is one of the most devastating cancers globally (1). The exceedingly poor prognosis for PDAC patients reflects a combination of late detection, rapid local invasiveness, and a severe lack of reliable biomarkers and efficacious treatment schemes (2). PDAC is associated with extensive metabolic changes, and PDAC tumors are accordingly highly acidic (3). While PDAC genotypes are highly complex, the most widely characterized driver mutations are activating KRAS mutations, inactivating $p 53$ tumor suppressor mutations, and inactivation or loss of the cyclin-dependent kinase inhibitor 2A (CDKN2A, P16INK4) and the transforming growth factor $\beta$ (TGF- $\beta$ ) effector, SMAD4 $(4,5)$.

TGF $\beta$ signaling involves the binding of a TGF $\beta$ dimer (TGF $\beta$ $1,-2$, or -3 , of which TGF $\beta-1$ is most ubiquitous) to the TGF $\beta$ receptor types I and II (TGFBRI and -II; the former also known as ALK5). This results in formation of a heterotetrameric receptor complex, where TGF $\beta$ RII phosphorylates and activates TGF $\beta$ RI. TGF $\beta$ RI in turn phosphorylates the transcription factors SMAD2/3, which bind to the co-SMAD, SMAD4, to form a hetero-trimeric protein complex that enters the nucleus to control gene expression. This complex may further interact with a variety of other transcription factors, which are necessary cofactors for SMAD-dependent gene regulation $(6,7)$. TGF $\beta$ ligands also signal through SMAD-independent pathways, including mitogen-activated protein kinases, small GTPases, and the phosphatidyl-inositol-3-kinase (PI3K)-AKT-mTOR pathway $(6,7)$.

In non-cancer epithelial cells and in premalignant cells, TGF $\beta$ signaling is consistently cytostatic, blocking cell cycle progression by increased expression of cyclin-dependent kinase (CDK) inhibitors. However, in many cancer cells, this is overridden by strong CDK activation by other pathways, causing TGF $\beta$ to be pro-tumorigenic (6). Accordingly, TGF $\beta$ signaling has been shown to stimulate cell motility, invasion, and proliferation, and limit antitumor immune response, and TGF $\beta$ RI inhibition can revert these effects $(8-10)$. Both pro- and antitumorigenic, highly genotype-dependent roles of TGF $\beta$ signaling were demonstrated in PDAC cells $(4,11-13)$. Illustrating the importance of TGF $\beta$ signaling in this cancer, a recent study showed that almost 50\% of PDAC patient tumors exhibited mutations in TGF- $\beta$ signaling components. While $S M A D 4$ inactivating mutations are most common, mutations in $S M A D 3$, TGF $\beta$ receptor type I (TGFBR1) and-2 (TFGBR2) are also reported (4).

TGF $\beta$ signaling is a major driver of epithelial-to-mesenchymal transition (EMT), a process with key roles in metastasis and chemotherapy resistance $(6,8,11,14-16)$. In PDAC, TGF $\beta$ induced EMT has been reported to involve SMAD4-dependent (17) and -independent (18) signaling, however, the process is incompletely understood.

Solid tumors are characterized by an often profoundly acidified extracellular $\mathrm{pH}\left(\mathrm{pH}_{\mathrm{e}}\right)$, a neutral or slightly increased intracellular $\mathrm{pH}\left(\mathrm{pH}_{\mathrm{i}}\right)$, and a greatly increased rate of acid extrusion $(19,20)$. The latter occurs because the acid generated by the high, predominantly glycolytic, metabolism of tumor cells is actively extruded from the cancer cells by specific transporters. These transporters, including the $\mathrm{Na}^{+} / \mathrm{H}^{+}$exchanger NHE1 (SLC9A1) and the $\mathrm{Na}^{+}, \mathrm{HCO}_{3}^{-}$cotransporters $\mathrm{NBCn} 1$ (SLC4A7) and NBCe2 (SLC4A5) confer additional advantages to the cancer cells, including stimulation of proliferation, survival, and invasiveness, leading to increased tumor growth and metastasis (21-24). In particular NHE1 is important for cell motility and invasiveness, which are key downstream events in EMT (25). Directly implying a link to TGF $\beta$, NHE1 is implicated in fibronectin release in a manner rescued by TGF $\beta-1$ (26).

We therefore hypothesized that net acid extruding proteins are regulated by TGF $\beta$ signaling in human PDAC cells and contribute to its downstream effects. We here show that TGF $\beta$-1induced EMT of Panc-1 cells is associated with increased protein levels of NHE1 and $\mathrm{NBCn} 1$ as well as increased $\mathrm{pH}_{\mathrm{i}}$, whereas smaller changes were observed in SMAD4-deficient BxPC-3 cells, which show only a very modest EMT. This difference between the two cell lines is corroborated in the opposite effects of TGF $\beta-1$ on proliferation, which is increased in Panc-1 and decreased in BxPC-3 cells. Furthermore, knockdown of the tumor suppressor Merlin potentiates TGF $\beta$-1-induced Panc-1 cell invasiveness in a manner dependent on both NHE1 and NBCn1. We propose that acid-extruding transporters are novel players in TGF $\beta$-1-induced EMT in PDAC cells.

\section{MATERIALS AND METHODS}

\section{Antibodies and Reagents}

Primary antibodies used in western blot analysis were: mouse anti- $\beta$-actin, mouse anti- $\alpha$-tubulin, and mouse anti- $\alpha$-smooth muscle actin ( $\alpha$-SMA), all from Sigma-Aldrich; goat polyclonal anti-CTGF and mouse anti-NHE1 (clone 54), anti-Poly-ADP Ribose Polymerase (PARP), anti-cleaved PARP (Asp214) and anti-pSer807/811-Rb, all from Santa Cruz Biotechnology; mouse anti-dynactin 1 (DCTN1) and mouse anti-E-cadherin, from BD Biosciences; rabbit anti-GAPDH, rabbit anti-Histone 3, rabbit anti-Merlin, mouse anti-p53, mouse anti-Ki67, and rabbit anti- $\beta$-catenin, all from Cell Signaling. Mouse anti- Ki-67 was from Dako (Glostrup, Denmark) and rabbit polyclonal 
anti-NBCn1 was a kind gift from Jeppe Prætorius, Aarhus University, Denmark. Secondary antibodies used in western blotting were horseradish-peroxidase-conjugated goat polyclonal anti-mouse or anti-rabbit and rabbit polyclonal anti-goat from Dako. Secondary antibodies for immunofluorescence analysis were AlexaFluor488-conjugated donkey anti-mouse or antirabbit, and AlexaFluor568-conjugted donkey anti-mouse or anti-rabbit, all from Invitrogen. Recombinant human TGF $\beta$ 1 (PHG9214) was from Life Technologies. Mouse monoclonal antibody against Proliferating cell nuclear antigen (PCNA) was from Cell Signaling Technology.

\section{Cell Culture}

Human PDAC cell lines MIAPaCa-2, Panc-1, BxPC-3, and AsPC-1 were acquired from American Type Culture Collection (ATCC, Rockville, MD, USA) and maintained in RPMI medium $1640+$ GlutaMAX $^{\mathrm{TM}}$-I or Dulbecco's Modified Eagle's medium (DMEM)+GlutaMAX ${ }^{\mathrm{TM}}$-I (both from Gibco) supplemented with $10 \%(\mathrm{v} / \mathrm{v})$ fetal bovine serum and $100 \mathrm{U} / \mathrm{ml}$ penicillin and $100 \mu \mathrm{g} / \mathrm{mL}$ streptomycin at $37^{\circ} \mathrm{C}$ in a humidified atmosphere of $5 \% \mathrm{CO}_{2}$. MIAPaCa- 2 cell medium was further supplemented with $2.5 \%(\mathrm{v} / \mathrm{v})$ heat-inactivated horse serum. Immortalized human pancreatic ductal epithelial (HPDE H6c7) cells were a kind gift from Dr. Ming-Sound Tsao at Ontario Cancer Institute, Toronto, Canada $(27,28)$ and were cultured in kerantinocyte basal medium supplemented with epidermal growth factor and bovine pituitary extract.

\section{siRNA-Mediated Knockdown}

siRNAs employed were: NHE1 siRNA: ON-TARGET SMART pool (Thermo Scientific); NBCn1 siRNA (SASI_Hs01_00030755, Sigma-Aldrich) sense sequence 5'-CAUUAACUGGGAUUG CCUA-3', Merlin siRNA (SASI_Hs_01_00188862, Sigma) sense sequence 5'-CCUCAAAGCUUCGUGUUAA-3; SMAD4 (EHU018671 esiRNA siRNA mixture, Sigma). A 19-bp scrambled oligomer (sense: 5'-AGGUAGUGUAAUCGC CUUG-3') (Eurofins MWG Operon, Ebersberg, Germany) was used for mock transfection. Cells were seeded to $\sim 40 \%$ confluency in the relevant culture dishes and transfected with NHE1 siRNA (100 nM), NBCn1 siRNA (25 nM), Merlin siRNA $(50 \mathrm{nM})$ or mock siRNA (50 nM), using Lipofectamine (Invitrogen) transfection reagent, according to the manufacturer's specifications. $48 \mathrm{~h}$ after transfection, cells were serum starved, and $24 \mathrm{~h}$ later, exposed to TGF $\beta$ treatment (or corresponding control conditions) for another $48 \mathrm{~h}$ before analysis for the relevant experiment as indicated below.

\section{RT-qPCR Analysis}

Total RNA was isolated using NucleoSpin ${ }^{\circledR}$ RNA II (MachereyNagel, Germany) according to the manufacturer's instructions, reverse-transcribed using Superscript III Reverse Transcriptase (Invitrogen, Carlsbad, CA) and cDNA transcripts were amplified by qPCR using the SYBR Green technique (Applied Biosystems, Cheshire, UK). Amplification was performed in triplicate in an ABI7900 qPCR machine, using 40 cycles of $\left(95^{\circ} \mathrm{C}\right.$ for $30 \mathrm{~s}, 60^{\circ} \mathrm{C}$ for $1 \mathrm{~min}, 72^{\circ} \mathrm{C}$ for $30 \mathrm{~s}$ ). Primer sequences were: NHE1-fw: 5'-CACACCACCATCAAATACTTCC-3', NHE1-rv:
5'-GAACTTGTTGATGAACCAGGTC-3'; NHE2-fw: TTG GAGAGTCCCTGCTGAATGATG, NHE2-rv: tcagctgtgatgt aggacaaataactg, NBCn1-fw: 5'-GCAAGAAACATTCTGACC CTCA-3', NBCn1-rv: 5'-GCTTCCACCACTTCCATTACzCT, NBCe2-fw: atcttcatggaccagcagatcac, NBCe2-rv: tgcttggctggcatc aggaag. mRNA expression was quantified using the comparative threshold cycle $(\mathrm{Ct})$ method, using $\beta$-actin as reference gene (fw 5' - AGCGAGCATCCCCCAAAGTT-3', rv 5'-GGGC ACGAAGGCTCATCATT- $3^{\prime}$ ), and is given relative to that in HPDE cells.

\section{SDS-PAGE and Western Blotting}

Cells were seeded to 60-70\% confluency in 6-well culture dishes, lysed in lysis buffer [1\% SDS, $10 \mathrm{mM}$ Tris-pH 7.5, $\mathrm{Na}_{3} \mathrm{VO}_{4}$ $1 \mathrm{mM}$, and complete protease inhibitor cocktail (Roche)] and homogenized by sonication. SDS-PAGE was performed using Bio-Rad Criterion ${ }^{\mathrm{TM}} \mathrm{TGX}^{\mathrm{TM}}$ precast $10 \%$ gels in Tris/Glycine buffer. Gels were run for $1 \mathrm{~h}$ at $150 \mathrm{~V}$, followed by transfer to Trans-Blot ${ }^{\circledR}$ Turbo $^{\mathrm{TM}} 0.2 \mu \mathrm{m}$ nitrocellulose membranes (Bio$\mathrm{Rad})$. Protein transfer was evaluated by Ponceau red staining, followed by blocking in 5\% dry milk in TBST $(0.01 \mathrm{M}$ Tris/HCl, $0.15 \mathrm{M} \mathrm{NaCl}, 0.1 \%$ Tween 20 ) for $30 \mathrm{~min}$ at room temperature, incubation with primary antibodies overnight at $4^{\circ} \mathrm{C}$, and finally washing in TBST and incubation with HRP-conjugated secondary antibodies for $2 \mathrm{~h}$ at room temperature. Blots were developed using the FUSION-Fx chemiluminescence system (Vilber Lourmat). Images were processed in Adobe Photoshop and band intensities were quantified using UN-SCAN-IT gel 6.1 software.

\section{Immunofluorescence Microscopy Analysis}

Cells were grown on glass coverslips in 6-well culture dishes, fixed in $4 \%$ paraformaldehyde for $15 \mathrm{~min}$ at room temperature, washed in icecold PBS, and permeabilized for $12 \mathrm{~min}$ in permeabilization buffer (0.2\% Triton X-100, 1\% BSA in PBS). Unspecific fluorescence was blocked by a $30 \mathrm{~min}$ incubation in PBS plus $2 \%$ BSA, followed by incubation with primary antibody for $1 \frac{1}{2} \mathrm{~h}$ at room temperature, three washes in $2 \%$ BSA blocking buffer, and incubation with secondary antibodies diluted in $2 \%$ BSA blocking buffer) for $45 \mathrm{~min}$, washing in PBS containing $2 \%$ $\mathrm{BSA}$, a 5 min incubation with (4,6-Diamidino-2-Phenylindole, Dihydrochloride) (DAPI) for nuclear staining, extensive washing in PBS and mounting in N-propyl-gallate mounting media (2\% $\mathrm{w} / \mathrm{v}$ in $\mathrm{PBS} /$ glycerin). Fluorescence images were captured on a fully motorized Olympus BX63 upright microscope with an Olympus DP72 color, 12.8-megapixel, $4.140 \times 3.096$-resolution camera and with a fully motorized and automated Olympus IX83 Inverted microscope with a Hamamatsu ORCA-Flash 4.0 camera (C11440-22CU). The software used was Olympus CellSens dimension, which is able to do deconvolution on captured $\mathrm{z}$ stacks, and images were processed for publication using Adobe Photoshop CS6.

\section{Real-Time Imaging of Intracellular pH}

Measurements of $\mathrm{pH}_{\mathrm{i}}$ were carried out essentially as described previously (21). Briefly, cells seeded in WillCo glass-bottom dishes (WillCo Wells, Amsterdam, the Netherlands) were loaded 
with $\quad 2^{\prime}, 7^{\prime}$-bis-(2-carboxyethyl)-5-(and-6)-carboxyfluorescein acetoxymethyl ester (BCECF-AM, $1.6 \mu \mathrm{M}$ ) in growth medium for $30 \mathrm{~min}$ at $37^{\circ} \mathrm{C}$. Cells were washed once in $\mathrm{HCO}_{3}^{-}$containing Ringer solution [118 mM NaCl, $25 \mathrm{mM} \mathrm{NaHCO}_{3}, 5 \mathrm{mM}$ $\mathrm{KCl}, 1 \mathrm{mM} \mathrm{MgSO}$, $1 \mathrm{mM} \mathrm{Na} \mathrm{HPO}_{4}, 1 \mathrm{mM} \mathrm{CaCl}, 3.3 \mathrm{mM}$ 3-(N-morpholino)propanesulfonic acid (MOPS), $3.3 \mathrm{mM} \mathrm{2-}$ [Tris(hydroxymethyl)-methylamino]-ethanesulfonic acid (TES), $5 \mathrm{mM}$ HEPES, $\mathrm{pH} 7.4$ ], placed in a $37^{\circ} \mathrm{C}$ imaging chamber equipped with gas and solute perfusion, at the stage of a Nikon Eclipse Ti microscope, and imaged using a 40X/1.4 NA objective and EasyRatioPro imaging software (PTI, NJ, USA). Emission was measured at $520 \mathrm{~nm}$ after excitation at 440 and $485 \mathrm{~nm}$. Acidification was induced by exposure to $20 \mathrm{mM} \mathrm{NH}_{4} \mathrm{Cl}$ for $10 \mathrm{~min}$. Calibration to $\mathrm{pH}_{\mathrm{i}}$ values was performed using the high $\mathrm{K}^{+}$/nigericin technique and a 4-point linear calibration curve.

\section{BrdU Proliferation Assay}

Eighty percentage confluent Panc-1 and BxPC3 cells were trypsinized and resuspended in growth medium. Cells were seeded in 96-well plates (Celllstar ${ }^{\circledR}$, cat \# 655090). After $24 \mathrm{~h}$ incubation at $37^{\circ} \mathrm{C} / 5 \% \mathrm{CO}_{2}$, plates were washed in $\mathrm{PBS}$ and $200 \mu \mathrm{l}$ serum free medium was added. After $24 \mathrm{~h}$, the cells were incubated with $10 \mathrm{ng} / \mathrm{mL} \mathrm{TGF} \beta$, and/or $10 \mu \mathrm{M}$ of the NHE1 inhibitor cariporide. Forty-eight hours later, a Cell Proliferation ELISA, BrdU (chemiluminescent) kit (Roche, cat \# 11669915 001) was used for determining the proliferation status of the cells, according to the manufacturer's instructions. $20 \mu \mathrm{l}$ BrdU labeling solution was added to each well and the plates were incubated for $4 \mathrm{~h}$, followed by a fixation/denaturing step, and incubation with a peroxidase-coupled mouse monoclonal anti-BrdU antibody. The plates were washed extensively, incubated with substrate solution containing luminol, 4-iodophenol and peroxide for $4 \mathrm{~min}$ on a shaker, and luminescence measured using a BMG FLUOstar OPTIMA Microplate Reader.

\section{Invasion Assay}

Cell invasion was assessed using growth factor reduced corning ${ }^{\circledR}$ Matrigel ${ }^{\circledR}$ invasion chambers, 24 -well plate and $8.0 \mu \mathrm{m}$ pore size (Corning, BioCoat, MA, USA). Prior to the experiment, invasion chambers containing Matrigel were rehydrated by adding 500 $\mu \mathrm{l}$ serum free medium for $2 \mathrm{~h}$ at $37^{\circ} \mathrm{C}$. Forty-eight hours after transfection with the indicated siRNAs, cells were serum starved, and $24 \mathrm{~h}$ later, treated or not with TGF $\beta$ for $48 \mathrm{~h}$, before being washed with sterile PBS, trypsinized, washed $3 \mathrm{x}$ in serum free medium, and 50,000 cells in this medium seeded into the upper chamber. Experiments were always done in duplicate. The lower chamber was filled with $10 \%$ serum containing medium. Chambers were incubated for $22 \mathrm{~h}$ at $37^{\circ} \mathrm{C} / 5 \% \mathrm{CO}_{2}$ to allow cells to invade through the Matrigel. Non-invaded cells from the upper surface of the chamber were removed with a cotton swab. Invaded cells on the lower surface of the chamber were fixed for $30 \mathrm{~min}$ in ice-cold absolute methanol, and filters were stained with $30 \%$ Giemsa solution (Sigma-Aldrich) for $30 \mathrm{~min}$ and mounted on glass slides. Invaded cells (four images per filter per condition) were counted using bright-field microscopy.

\section{Data Analysis and Statistics}

Data are shown as individual representative experiments or as means of at least three independent experiments, with standard error of mean (SEM) error bars. Statistical significance was tested using Student $t$-test or one- or two-way ANOVA followed by Tukey's multiple comparison tests as appropriate, using GraphPad prism 6.

\section{RESULTS}

\section{Expression of Net Acid Extruding Transporters Is Increased in PDAC Cells}

Our previous in silico analysis of RNA sequencing data from pancreatic cancer patient tissue indicated that a number of SLC9 and SLC4 family transporters are upregulated in PDAC patient tumor tissue compared to normal pancreatic epithelium (29). From these, we selected for widely expressed net acid extruders for initial analyses: two $\mathrm{Na}^{+} / \mathrm{H}^{+}$exchangers, NHE1 and-2 (SLC9A1-2), and two $\mathrm{Na}^{+}, \mathrm{HCO}_{3}^{-}$cotransporters (NBCs), NBCe2 (SLC4A5) and NBCn1 (SLC4A7). The relative mRNA levels of the transporters were determined by RT-qPCR analysis in immortalized pancreatic epithelial (HPDE) cells $(27,28)$, and in a panel of human PDAC cell lines of different genotypes: MIAPaCa-2, Panc-1, BxPC-3, and AsPC-1 cells. All PDAC cell lines studied exhibited increased mRNA levels of one or more of these transporters compared to HPDE cells, with the specific transporters upregulated differing between cell lines (Figures 1A,B). Thus, BxPC-3 and AsPC-1 cells showed elevated expression of NHE1 and-2, and MIAPaCa-2 cells predominantly showed upregulation of $\mathrm{NBCn} 1$ and $\mathrm{NBCe} 2$, while both NHE2 and NBCn1 were upregulated in Panc-1 cells. For further analyses, we focused on NHE1 and NBCn1, which play central roles in the development of PDAC and other cancers $(21,22,24,30-33)$. Consistent with the mRNA data, western blot analysis revealed that the NHE1 protein level was significantly increased in BxPC-3 cells and the NBCn1 protein level in MIAPaCa-2 and Panc-1 cells, compared to that observed in HPDE cells (Figures 1C,D).

These data show that net acid extruding proteins are upregulated in PDAC cells compared to normal pancreatic ductal epithelial cells, and that the specific pattern of upregulation is cell type dependent.

\section{TGF $\beta$-1 Treatment Elicits a SMAD4-Dependent EMT in PDAC Cells}

BxPC-3 and Panc-1 cells, which display a high levels of NHE1 and NBCn1 expression, respectively, were chosen for further analysis. We first assessed the ability of TGF $\beta$ ligand to induce EMT in the two cell lines. Cells were serum-starved for $24 \mathrm{~h}$, followed by treatment with $10 \mathrm{ng} / \mathrm{ml}$ human recombinant TGF $\beta$ 1 for $48 \mathrm{~h}$. After lysis, cells were subjected to western blot analysis for the epithelial marker E-cadherin as well as the mesenchymal markers $\alpha$-smooth muscle actin ( $\alpha$-SMA) and connective tissue growth factor (CTGF) (Figure 2A). In Panc-1 cells, TGF $\beta-1$ treatment significantly reduced the level of E-cadherin, and increased that of $\alpha$-SMA and CTGF, consistent with induction of 

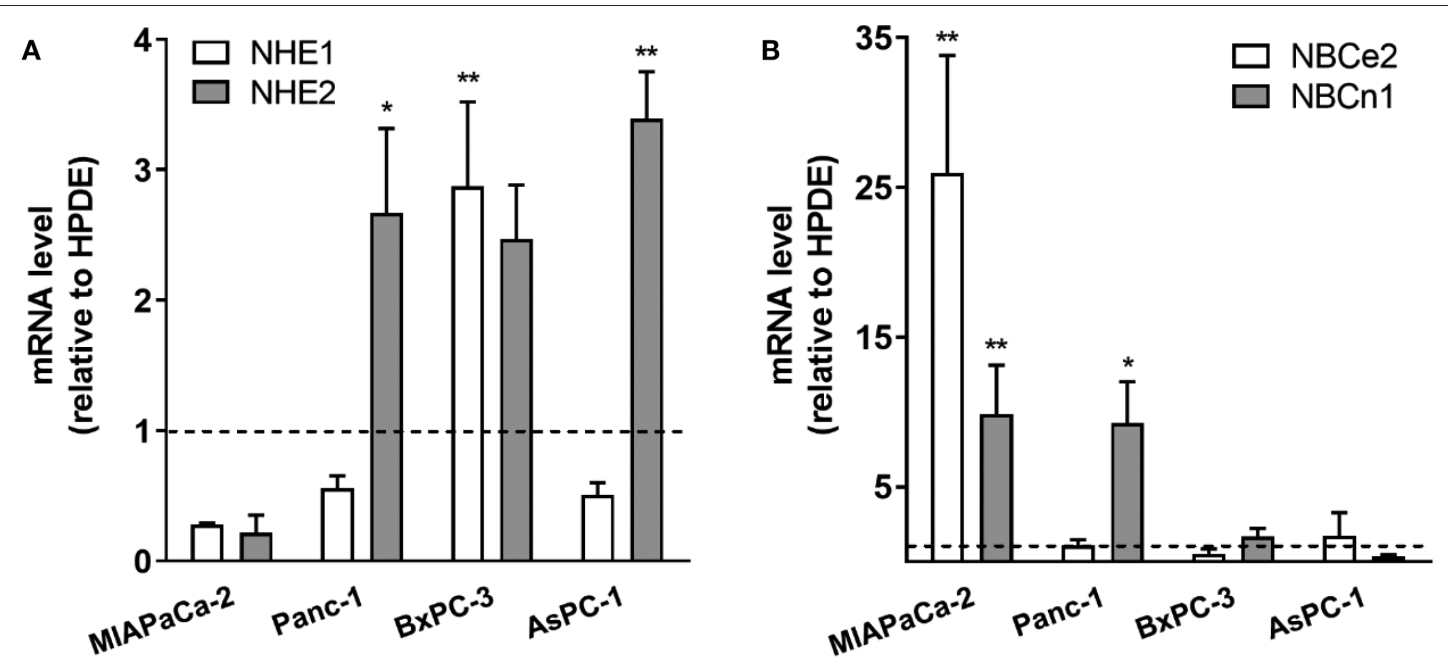

C

D
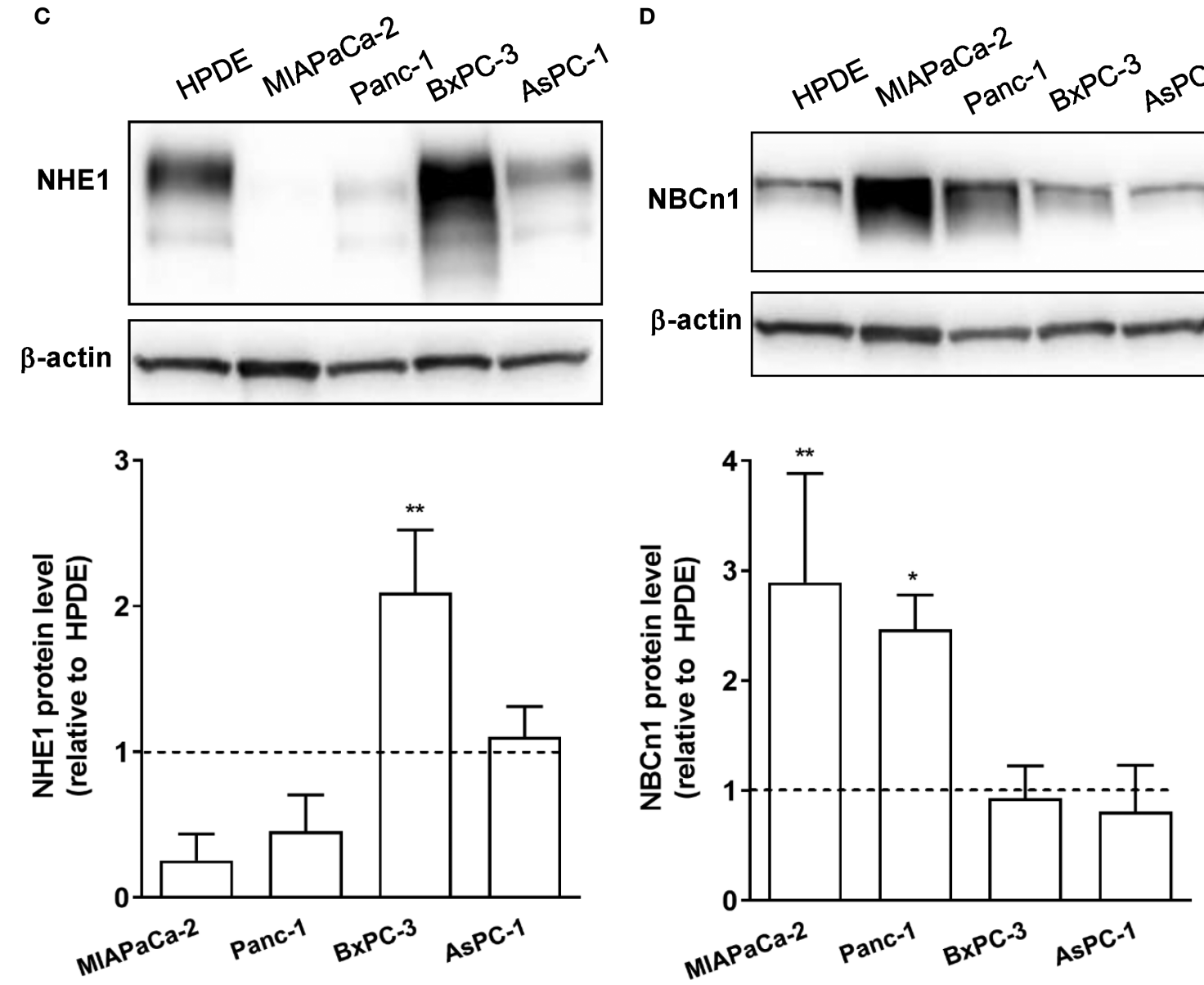

FIGURE 1 | mRNA and protein expression of net acid extruding transporters is upregulated in PDAC cells compared to normal pancreatic ductal epithelial cells. (A,B) Immortalized pancreatic ductal epithelial (HPDE) cells and a panel of PDAC cell lines: MIAPaCa-2, Panc-1, BxPC-3, and AsPC-1 cells, were grown to about 80\% confluence, lysed and mRNA expression of NHE1 and-2 (A) and NBCe2 and NBCn1 (B) analyzed by RT-qPCR. Data (mean with S.E.M. error bars) are normalized to the expression level in HPDE cells in the same experiment (shown as a dotted line). (C,D) HPDE, MIAPaCa-2, Panc-1, BxPC-3, and AsPC-1 cells were grown to about $80 \%$ confluence, lysed and protein levels of NHE1 (C) and NBCn1 (D) analyzed by Western blotting. Data (mean with S.E.M. error bars) are normalized to the $\beta$-actin loading control and to the expression level in HPDE cells in the same experiment (shown as a dotted line). $n=3-4$ independent experiments per condition in all panels. ", ${ }^{* *}$ One-way ANOVA, $p<0.05$ and 0.01, respectively, against the level in HPDE cells. 
EMT (Figures 2A,B). In BxPC-3 cells, TGF $\beta$ - 1 treatment elicited a small yet significant decrease in E-cadherin of about $25 \%$, which was not accompanied by detectable changes in $\alpha$-SMA and CTGF expression (Figures 2A,C). Immunofluorescence analysis was performed to assess the impact of TGF $\beta$ - 1 treatment on cell morphology and protein localization in Panc-1 cells. TGF $\beta-1$ treatment induced a marked internalization of both E-cadherin and $\beta$-catenin (arrows), a strong, predominantly membraneassociated increase in $\alpha$-SMA, and increased intracellular CTGF expression (Figure 2D).

These data show that TGF $\beta$-1 treatment elicited a marked EMT in Panc- 1 cells, and a modest and partial EMT in BxPC3 cells.

BxPC-3 cells are SMAD4-deficient (34), which has previously been shown to be responsible for their partial resistance to TGF $\beta$-1-induced EMT (14), although the absolute requirement for SMAD4 for TGF $\beta$-1-induced EMT is controversial $(14,35)$. To assess the role of SMAD4 in TGF $\beta$-1-induced EMT in Panc-1 cells, we knocked down SMAD4 by siRNA in Panc1 cells, followed by TGF $\beta$ - 1 treatment for $48 \mathrm{~h}$, and western blotting for E-cadherin and CTGF (Figures 2E-H). In mocktransfected cells, TGF $\beta-1$ treatment almost doubled the level of SMAD4. Confirming efficient knockdown, the SMAD4 protein level was reduced by more than $80 \%$ in SMAD4 siRNA-treated cells (Figures 2E,F). Notably, the E-cadherin level was more than doubled by SMAD4 knockdown in the absence of TGF $\beta$ 1 , and this was only marginally reduced by TGF $\beta$-1-induced increase in CTGF expression was abolished in SMAD4-depleted cells (Figure 2G). Conversely, SMAD4 knockdown had no effect on the CTGF level under control conditions yet abolished the increase in CTGF induced by TGF $\beta-1$ treatment (Figure $2 \mathbf{H}$ ).

Collectively, these data show that TGF $\beta-1$ induced EMT in Panc- 1 cells is strongly dependent on SMAD4 and suggest that a basal level of SMAD4 signaling in the absence of TGF $\beta-1$ treatment is responsible for the low basal E-cadherin level in these cells.

\section{NHE1 Expression Is Increased in a SMAD-Dependent Manner During TGF $\beta$-1-Induced EMT}

We next asked whether TGF $\beta$-1 treatment altered NHE1 and NBCn1 expression in Panc-1 and BxPC-3 cells. The protein expression level of NHE1 increased by about $60 \%$, and that of NBCn1 by about $40 \%$, following TGF $\beta$ - 1 treatment of Panc- 1 cells (Figures 3A,B), and a similar, albeit non-significant trend was seen in BxPC-3 cells (Figures 3A,C). The mRNA level of NHE1 also tended to be upregulated by TGF $\beta-1$ in Panc- 1 cells, and that of NBCn1 in BxPC-3 cells (Figures 3C,D). The TGF $\beta$ 1 -induced increase in NHE1 expression was strongly reduced by SMAD4 knockdown in Panc-1 cells (Figures 3E,F), whereas the modest increase in NBCn 1 expression was not affected by SMAD4 knockdown (Figures 3E,G). This suggests that increased NHE1 expression is mainly mediated by canonical TGF $\beta$ signaling, whereas the effect of TGF $\beta-1$ on NBCn1 expression appears to be mediated by non-canonical signaling events. Both transporters localize predominantly to the plasma membrane in both cell types. Interestingly, TGF $\beta-1$ treatment caused a characteristic redistribution of $\mathrm{NBCn} 1$ to membrane ruffles in BxPC-3 cells (Figure 3I) whereas there was no detectable redistribution in Panc-1 cells (Figure 3H).

To determine whether NHE1 and NBCn1 played a role in the EMT process per se, we knocked down each transporter in Panc-1 cells and subjected the cells to $48 \mathrm{~h}$ of TGF $\beta$ - 1 treatment as above, followed by western blotting for E-cadherin and CTGF. Although the protein level of both transporters was essentially abolished upon siRNA treatment, this did not detectably affect TGF $\beta$ 1-induced E-cadherin downregulation or CTGF upregulation (Supplementary Figure 1).

These results show that TGF $\beta-1$ induced EMT is associated with increased expression of NHE1 and NBCn1 and increased localization of the transporters at the plasma membrane where they could increase net acid extrusion from the cells. However, neither transporter is required for induction of EMT per se.

\section{TGF $\beta$-1 Increases Steady State $\mathrm{pH}_{\mathrm{i}}$ and NHE1-Dependent Acid Extrusion in Panc-1 Cells}

To directly determine whether the changes in transporter expression upon TGF $\beta$-1-induced EMT are associated with altered $\mathrm{pH}_{\mathrm{i}}$ homeostasis, cells were subjected to TGF $\beta-1$ treatment for $48 \mathrm{~h}$, loaded with the $\mathrm{pH}_{\mathrm{i}}$ sensitive fluorophore BCECF-AM, and steady state pHi determined by live imaging of BCECF fluorescence. Experiments were carried out in the presence of $\mathrm{CO}_{2} / \mathrm{HCO}_{3}^{-}$to allow contributions from bicarbonate-dependent transporters such as NBCn1. TGF $\beta-1$ treatment significantly increased steady state $\mathrm{pH}_{\mathrm{i}}$ in Panc- 1 cells, from an average value of $7.06 \pm 0.105$ in control cells to 7.26 \pm 0.043 after TGF $\beta-1$ treatment (Figure 4A). In contrast, the steady state $\mathrm{pH}_{\mathrm{i}}$ of $\mathrm{BxPC}-3$ cells was $7.01 \pm 0.062$ in controls and $7.09 \pm 0.066$ after TGF $\beta-1$ treatment, not significantly different (Figure 4B).

To evaluate whether cellular capacity for acid extrusion was increased by TGF $\beta$-1 treatment, we next determined the $\mathrm{pH}_{\mathrm{i}}$ recovery rate. Cells were pretreated with or without TGF $\beta-1$ for $48 \mathrm{~h}$ as above, and subjected to an $\mathrm{NH}_{4} \mathrm{Cl}$-prepulse to acidify the cells: after equilibration in normal $\mathrm{CO}_{2} / \mathrm{HCO}_{3}^{-}$saline, cells were perfused with $15 \mathrm{mM} \mathrm{NH}_{4} \mathrm{Cl}$. Upon dissociation, $\mathrm{NH}_{3}$ rapidly enters the cells by diffusion. Its association with cellular $\mathrm{H}^{+}$ to $\mathrm{NH}_{4}^{+}$causes near-instantaneous alkalinization, followed by slow return toward steady state $\mathrm{pH}_{\mathrm{i}}$ as $\mathrm{NH}_{4}^{+}$from the solution enters the cells via ion transporters, shifting the equilibrium. When cells are again perfused with normal $\mathrm{CO}_{2} / \mathrm{HCO}_{3}^{-}$saline, all $\mathrm{NH}_{3}$ rapidly diffuses out, and an excess of free $\mathrm{H}^{+}$is left in the cells. The rate of recovery from this acidification is a measure of net acid extrusion capacity, determined as the slope of the initial, linear part of the curve under conditions where starting $\mathrm{pH}_{\mathrm{i}}$ is similar (36). Experiments were again carried out in the presence of $\mathrm{CO}_{2} / \mathrm{HCO}_{3}^{-}$. Figures $4 \mathrm{C}$, $\mathrm{D}$ shows representative traces of $\mathrm{pH}_{\mathrm{i}}$ over time from the maximal acidification. As seen, TGF $\beta$ - 1 treatment markedly increased the $\mathrm{pH}_{\mathrm{i}}$ recovery rate in Panc-1 cells (Figure 4C) but not in BxPC-3 cells (Figure 4D). NHE1 and NBCn1 activity is posttranslationally regulated (37, 
A

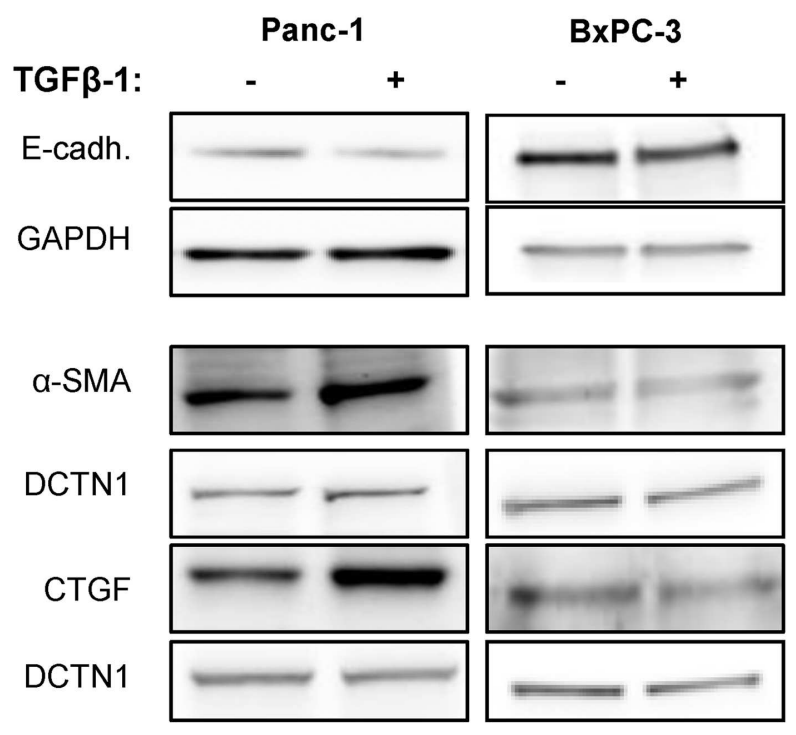

D

Panc-1

B

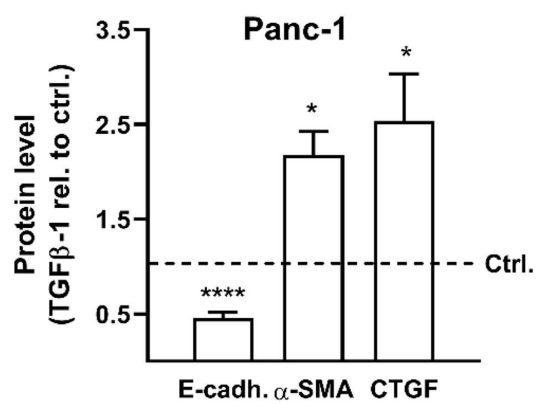

C

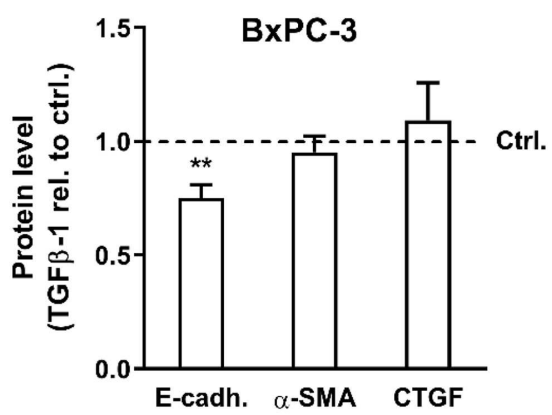

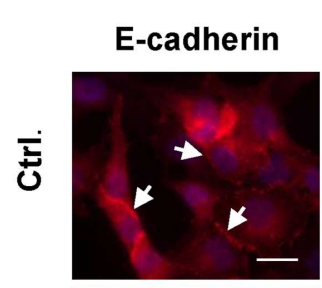
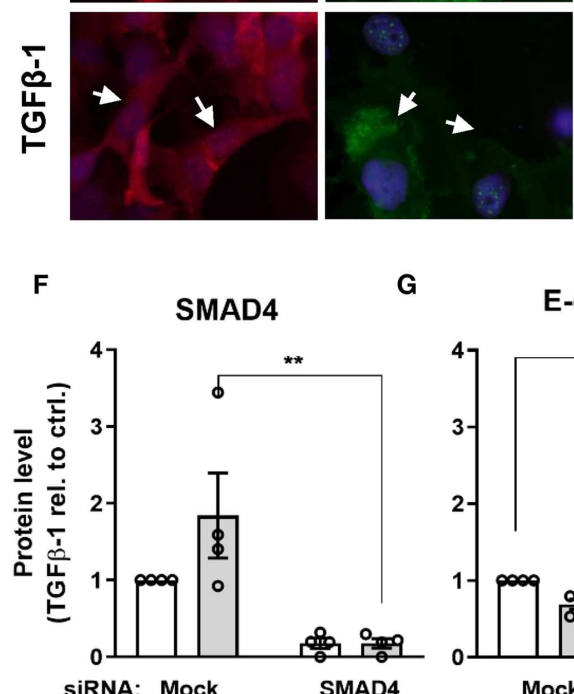

G
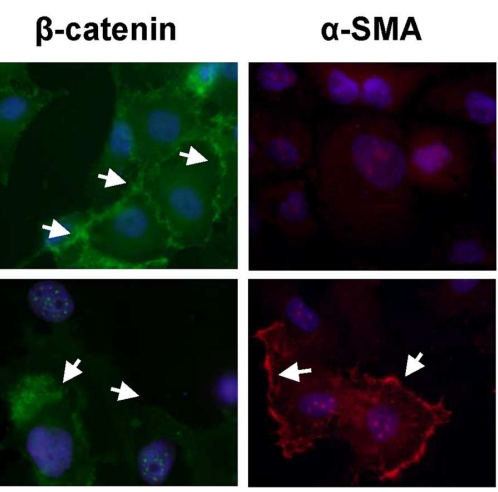

E-cadh.

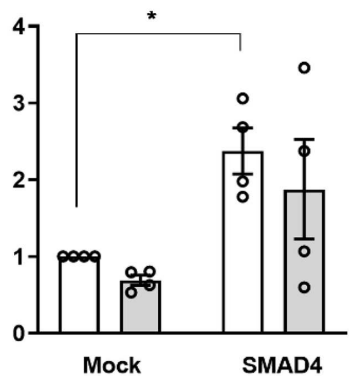

H

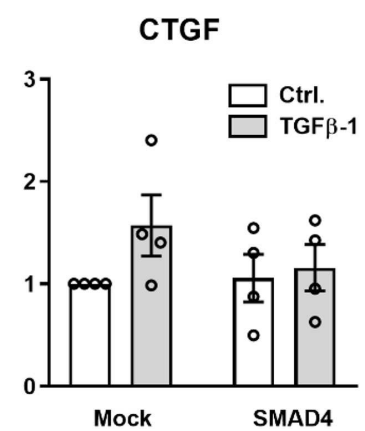

E

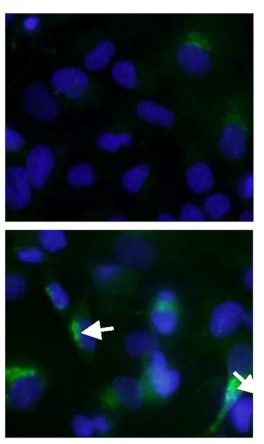

Panc-1

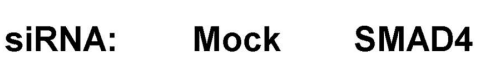

TGF $\beta-1:-+\quad+$

SMAD4

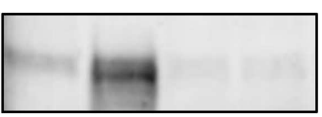

E-cadh

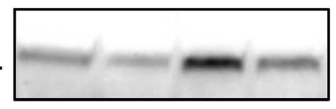

$\beta$-actin

CTGF

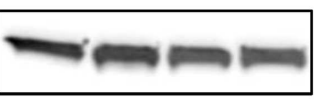

H3

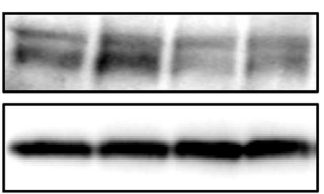

FIGURE 2 | TGF $\beta$-induces a predominantly SMAD4-dependent EMT. (A) Panc-1 and BxPC-3 cells were serum starved for $24 \mathrm{~h}$, followed by $48 \mathrm{~h}$ growth with or without $10 \mathrm{ng} / \mathrm{ml}$ human recombinant TGF $\beta-1$ for $48 \mathrm{~h}$ as indicated. Cells were lysed and subjected to western blotting for E-cadherin, $\alpha$-SMA, and CTGF, using GAPDH and DCTN1 as loading markers. Representative western blots are shown. (B,C) Summarized, quantified data from experiments as in (A), for Panc-1 cells (B) and BxPC-3 cells (C). Data (mean with S.E.M. error bars) were normalized to loading control and to the level in the absence of TGF $\beta-1$ (Ctrl.), shown by the dotted line. $n=3-8$ independent experiments per condition. ${ }^{*},{ }^{* *},{ }^{* \star \star \star}$ One-way ANOVA, $p<0.05,0.01,0.0001$, respectively, against the level in non-TGF $\beta-1$ treated control cells. (D) Immunofluorescence microscopy analysis of the localization and expression level of E-cadherin, $\beta$-catenin, $\alpha$-SMA and CTGF in Panc-1 cells. Nuclei are stained using DAPI. The images shown are representative of at least three independent experiments per condition. Arrows indicate the distinct plasma membrane localization of E-cadherin and $\beta$-catenin under control conditions and the shift in localization upon TGF $\beta$-1 treatment. (E-H) Effect of SMAD4 knockdown in Panc-1 
FIGURE 2 | cells on E-cadherin and CTGF protein levels. E, representative western blot, F-H, SMAD4, E-cadherin, and CTGF protein levels, normalized to mock ctrl. and shown as mean with S.E.M. error bars and individual data points. Relative to mock siRNA-treated controls, SMAD4 expression was $1.8 \pm 0.55$ in mock siRNA + TGF $\beta-1$ treated cells, $0.18 \pm 0.066$ in SMAD4 siRNA treated cells, and $0.18 \pm 0.063$ in SMAD4 siRNA + TGF $\beta$ - 1 treated cells. $\beta$-actin and Histone 3 (H3) are used as loading markers. Data are from four independent experiments per condition. *, ** One-way ANOVA, $p<0.05,0.01$, respectively.

38), hence, their contributions to $\mathrm{pH}_{\mathrm{i}}$ regulation are not predicted by their protein levels. Notably, in both Panc-1 and BxPC-3 cells, $\mathrm{pH}_{\mathrm{i}}$ recovery in both control- and TGF $\beta$ - 1 treated cells was abolished by the specific NHE1 inhibitor cariporide regardless of (Figures 4E,F).

Collectively, these results show that TGF $\beta$-1-induced EMT in Panc- 1 cells is associated with increased steady state $\mathrm{pH}_{\mathrm{i}}$ and increased NHE1-dependent acid extrusion capacity.

\section{TGF $\beta$-1 Differentially Regulates Cell Proliferation in Panc-1 and BxPC-3 Cells}

Depending on the cell type and context, TGF $\beta$ signaling can counteract or stimulate cell proliferation, and this has been ascribed at least in part to SMAD2/3 signaling, which rely on SMAD4 $(4,6)$. We therefore assessed the impact of TGF $\beta$ 1 treatment on cell proliferation in Panc-1 and BxPC-3 cells. Cells treated for $48 \mathrm{~h}$ with or without TGF $\beta$-1 were lysed and blotted for phosphorylated retinoblastoma protein $(\mathrm{p}-\mathrm{pRb})$ and proliferating cell nuclear antigen (PCNA) as markers of cell cycle entry and progression, respectively. Notably, TGF $\beta$ - 1 treatment increased the $\mathrm{p}-\mathrm{pRb}$ level in Panc-1 cells yet decreased it in BxPC-3 cells (Figures 5A,B), and similar results were obtained for PCNA (Figures 5A,C). This was confirmed by IFM analysis using Ki-67 as a proliferation marker: The fraction of Ki-67 positive cells was decreased in both cell types-although most dramatically in Panc-1 cells-by $48 \mathrm{~h}$ of serum starvation, and was increased in Panc-1 cells, yet decreased in BxPC-3 cells by TGF $\beta-1$ (Figures 5D-F). Strikingly, TGF $\beta-1$ treatment also increased p53 expression in Panc- 1 cells, but not in BxPC-3 cells (Figure 5G). Co-staining for p53 and p-pRb confirmed these data and revealed that elevation of nuclear staining for $\mathrm{p}-\mathrm{pRb}$ and $\mathrm{p} 53$ was detected within the same cells (Supplementary Figure 2). BrdU incorporation analysis confirmed that TGF $\beta-1$ treatment increased proliferation of Panc-1 cells, yet decreased that of BxPC-3 cells, and showed that proliferation was unaffected by inhibition of NHE1 (10 $\mu$ M cariporide) or NBCs (10 $\mu$ M S0859), under both basal and TGF $\beta$-1-treated conditions (Figures 5H,I).

Taken together, these results show that TGF $\beta-1$ treatment stimulates proliferation of Panc-1 cells yet inhibits that of BxPC3 cells. This occurs in parallel with a TGF $\beta$-1-induced increase in p53 expression in the Panc- 1 cells and is unaffected by inhibition of NHE1 or NBCn1.

\section{Loss of Merlin Stimulates TGF $\beta$-1-Induced Invasiveness in an NHE1- and NBCn1-Dependent Manner}

Previous studies have demonstrated the involvement of acid-base transporters in cell motility and invasiveness, through roles of the transporters in cell adhesion, cytoskeletal dynamics, and matrix degradation $(19,25,39-41)$. We therefore asked whether the
TGF $\beta$-1-induced upregulation of NHE1 and NBCn1 contributed to TGF $\beta$-1-induced invasiveness of Panc-1 cells.

Stimulation with TGF $\beta-1$ increased invasion of Panc-1 cells through Matrigel more than 4-fold (Figure 6B), consistent with the strong TGF $\beta$-1-induced EMT induction in these cells (Figure 2). siRNA-mediated knockdown of NHE1 further increased TGF $\beta$-1-induced invasiveness, whereas knockdown of $\mathrm{NBCn} 1$ or both transporters in combination had no effect (Figures 6A,B). The unexpected exacerbation of invasiveness by NHE1 knockdown prompted us to ask whether the impact of NHE1 on PDAC cell invasiveness was genotype-dependent. The tumor suppressor Merlin (aka Neurofibromatosis type 2, NF2), which is downregulated in many PDAC tumors (42), was reported to regulate EMT (43) and cell motility (44), and was recently shown to regulate NHE1 in melanoma cells (45). siRNA-mediated knockdown of Merlin (Figure 6A) increased basal invasion 4-fold and almost doubled TGF $\beta$-1-induced invasiveness (Figure 6C). Notably, in Merlin-depleted cells, knockdown of either NHE1 or NBCn1 abolished the increase in invasion (Figure 6C).

These results show that Merlin depletion increases basal invasion and potentiated TGF $\beta$-1-induced invasiveness. Invasion induced by Merlin depletion, but not that induced by TGF $\beta-1$ alone, is dependent on NHE1 and NBCn1.

\section{DISCUSSION}

Pancreatic cancer has one of the most ominous mortality rates of any cancer globally, and the relative burden of disease is expected to increase over the next decade (1). PDAC tumors frequently exhibit abundant secretion of TGF $\beta$ from both stromal and tumor cells (46). Another characteristic of PDAC is extensive EMT $(14,15)$, the roles of which in PDAC development are incompletely understood $(11,16)$.

An emerging hallmark of solid tumors is profound dysregulation of $\mathrm{pH}$ homeostasis and upregulation of net acid-extruding transport proteins which play important roles in cancer development $(19,20)$. Given the extreme acid-base homeostasis of the pancreas under physiological conditions (3), PDAC is particularly interesting in this context. Here, we asked whether TGF $\beta$-1-induced EMT in PDAC cells is associated with upregulation of net acid extruding transporters. We focused on NHE1 and NBCn1, which we and others have shown to play important roles in cancer development (21-24), and found that these transporters were upregulated in PDAC cell lines compared to normal controls. The great majority of patient PDAC tumors show activating KRAS mutations, and about 50\% show mutations in TGF $\beta$ pathway components, 


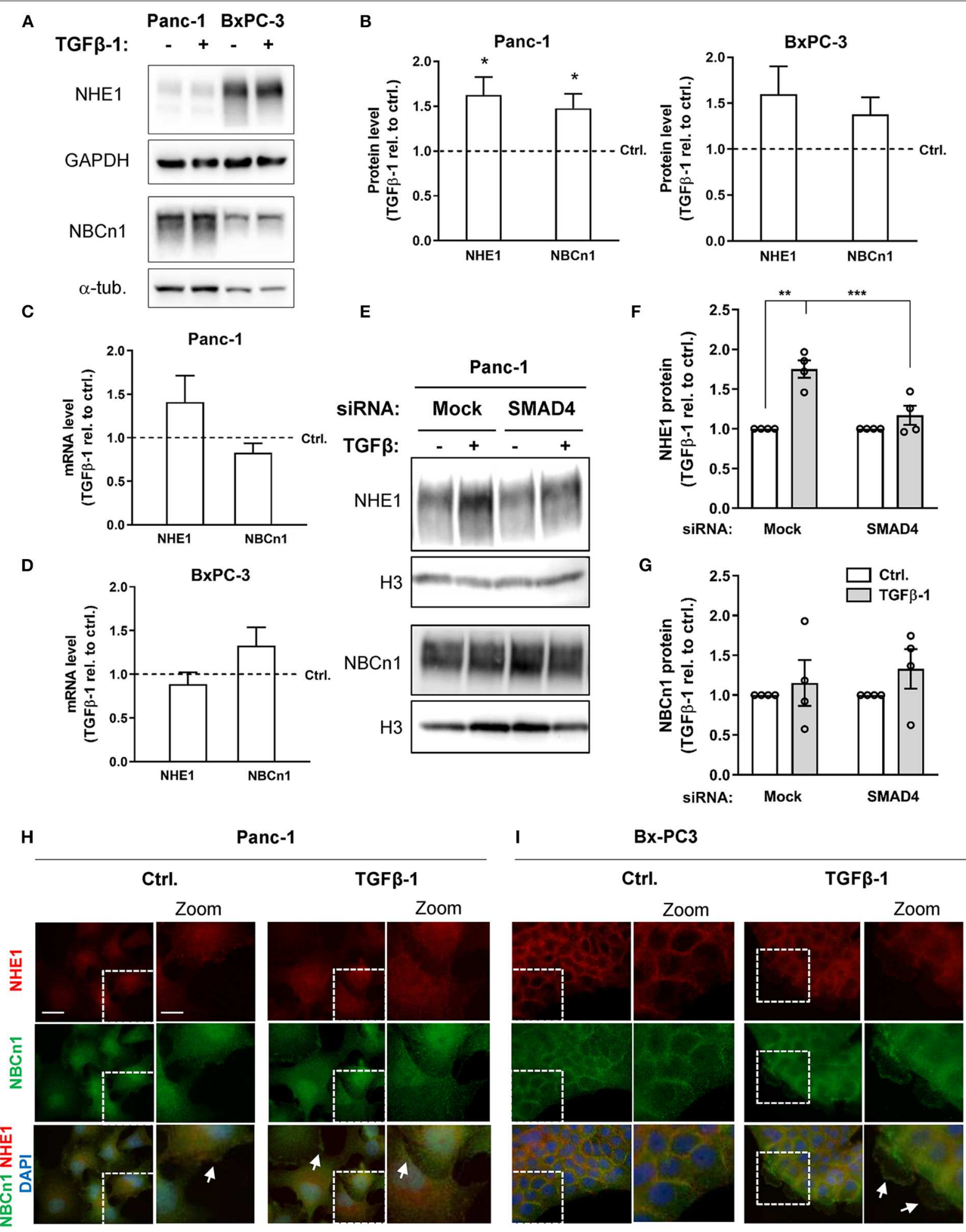

FIGURE 3 | NHE1 and NBCn1 protein expression is upregulated during TGF $\beta$-induced EMT. (A,B) Following growth in absence or presence of $10 \mathrm{ng} / \mathrm{ml}$ human recombinant TGF $\beta-1$ for $48 \mathrm{~h}$, cells were lysed and subjected to western blotting for NHE1 and NBCn1. (A) representative blots, with GAPDH and $\alpha$-tubulin as loading markers. (B) quantified data for Panc-1 and BxPC-3 cells, shown as mean with S.E.M. error bars, normalized to the level in absence of TGF $\beta$-1 (represented by the dotted line). Data shown represent $n=3-8$ per condition. * One-way ANOVA, $p<0.05$, against the level in non-TGF- $\beta$ treated control cells. (C,D) Panc-1 (C) and BxPC-3 (D) cells were serum-starved for $24 \mathrm{~h}$, followed by TGF $\beta-1$ treatment as above for $48 \mathrm{~h}$. mRNA levels were determined by qPCR and normalized to 
FIGURE 3 | non-TGF- $\beta$ treated control cells. Data are mean with S.E.M. error bars, of 8-11 independent experiments per condition. (E-G) Effect of SMAD4 knockdown on NHE1 and NBCn1 protein levels in Panc-1 cells. (E) representative western blot, (F,G) NHE1 and NBCn1 protein levels, normalized to mock ctrl. and shown as mean with S.E.M. error bars and individual data points. Data shown are from 4 independent experiments per condition. For SMAD4 knockdown efficiency, see Figure 2E and Figure 2 legend. ${ }^{* \star}$, ${ }^{* \star \star}$ One-way ANOVA, $p<0.05,0.01$, respectively. (H,I) IFM analysis illustrating the localization and expression level of native NHE1 (red) and NBCn1 (green) in Panc-1 (H) and BxPC-3 (I) cells. Nuclei are stained using DAPI. Images shown represent at least three independent experiments per condition. Scale bars are $20 \mu \mathrm{m}$, and $10 \mu \mathrm{m}$ in the zoomed images.

most commonly SMAD4 loss or inactivating mutations (4). For further analysis we therefore selected Panc-1 cells, which harbor an activating KRAS mutation and express wild type SMAD4, and BxPC-3 cells, which are KRAS wild type and express a truncated, defective version of SMAD4 (34). Consistent with previous reports $(14,15,35), 48 \mathrm{~h}$ TGF $\beta-1$ treatment robustly induced EMT characteristics, i.e., downregulation of E-cadherin, upregulation of $\alpha$-SMA and CTGF, and internalization of $\beta$-catenin in Panc-1 cells, compared to a partial EMT in BxPC-3 cells where only E-cadherin expression was detectably altered. Accordingly, SMAD4 knockdown in Panc-1 cells largely abolished EMT. EMT has been reported to involve both SMAD4-dependent (17) and-independent (18) processes. TGF $\beta$-induced E-cadherin downregulation in Panc-1 cells and other PDAC cell lines was reported to be nearly completely dependent on SMAD3 and SMAD4, as well as the EMT-associated transcription factors SLUG and SNAIL, which are activated downstream from SMAD4 (35). The SMAD3-4 complex binds and activates the SNAIL promoter, in turn leading to the SNAIL-dependent E-cadherin downregulation (47). However, non-canonical TGF $\beta$ pathways including ERK1/2 were also reported to contribute to EMT (35), consistent with our finding of partial EMT induction in BxPC-3 cells (34).

A central finding of this work was that TGF $\beta$-1-induced EMT was associated with upregulation of NHE1, and to a lesser extent NBCn1, expression in Panc-1 cells. Consistent with this, NHE1 was recently proposed to be upregulated by ZEB1, a transcription factor involved in driving EMT (48). Knockdown of the NHE1 or NBCn1 had no detectable effect on EMT induction per se (E-cadherin, CTGF and $\alpha$-SMA levels). However, in congruence with the transporter upregulation, EMT induction was associated with an increase in steady state $\mathrm{pH}_{\mathrm{i}}$ and increased capacity for net acid extrusion in Panc-1 cells but not in BxPC3 cells. Acid extrusion was potently inhibited by the NHE1 inhibitor Cariporide in both cell lines, despite the presence of $\mathrm{CO}_{2} / \mathrm{HCO}_{3}^{-}$and the relatively high expression of $\mathrm{NBCn} 1$ in the Panc-1 cells. Both cell lines also express NHE2 at rather high levels (Figure 1A). With reported Ki values for Cariporide of $0.05 \mu \mathrm{M}$ for NHE1 and $3 \mu \mathrm{M}$ for NHE2 in transfected fibroblasts (49), it seems likely that both isoforms might contribute to this recovery (see also below). Notably, the stimulatory effect of TGF $\beta$ on $\mathrm{pH}_{\mathrm{i}}$ regulation in Panc-1 cells differs from the reported inhibitory effect of TGF $\beta$ on $\mathrm{pH}_{\mathrm{i}}$ regulation in noncancer hepatocytes (50). Thus, it appears that, fully in line with the opposite effects of TGF $\beta$ signaling on proliferation and survival in cancer- and non-cancer cells $(6,8)$, TGF $\beta$ attenuates $\mathrm{pH}_{\mathrm{i}}$ regulation in normal cells, yet stimulates it in some cancer cells.
TGF $\beta$ - 1 treatment significantly increased proliferation of the SMAD4-positive Panc-1 cells, while decreasing it in the SMAD4deficient BxPC-3 cells. Paradoxically, at the same time, TGF $\beta$ treatment increased p53 expression in Panc-1 cells but not in BxPC- 3 cells. Thus, clearly, the presence of SMAD4 and TGF $\beta$ 1 -induced p53 signaling does not prevent a pro-proliferative effect of the ligand. Both TGF $\beta$ and acid extruding proteins are important regulators of cell proliferation/death balance, and EMT has recently been recognized to play important roles also in control of cancer cell survival $(11,16)$. We therefore reasoned that transporter upregulation might regulate the balance between pro-death and pro-growth effects of TGF $\beta$ in PDAC, yet, inhibition of NHE1 or NBCs did not affect proliferation of either cell line under these conditions. It remains possible that such effects might be uncovered in the severely nutrient-deprived and hypoxic tumor microenvironment, where NHE1 has been proposed to play a role in nutrient uptake in PDAC cells via macropinocytosis (51).

Given the roles of $\mathrm{pH}_{\mathrm{i}}$ and $\mathrm{pH}_{\mathrm{e}}$ in general, and NHE1 and $\mathrm{NBCn} 1$ in particular, in cancer cell motility and invasion $(19,25$, 39-41), we asked whether NHE1 and NBCn1 impacted TGF $\beta$ 1 -induced invasiveness. Forty-eight hours of TGF $\beta$-1 treatment robustly increased invasiveness of Panc-1 cells and this was not abolished by transporter knockdown; in fact, siRNA-mediated depletion of NHE1 modestly increased invasiveness, a finding reminiscent of our demonstration that counter to its general role in favoring motility and invasiveness (25), NHE1 inhibition actually increased motility of p95HER-overexpressing breast cancer cells, while inhibition of NBCs had no effect (52). The lack of effect of NHE1 knockdown shown here contrasts the conclusion of a recent report using $10 \mu \mathrm{M}$ cariporide to inhibit NHE1 (32). Since NHE1 knockdown was highly efficient in our study, it seems possible that the effect of cariporide may reflect a contribution of NHE2, which, as noted above, would also have been inhibited at this concentration. The tumor suppressor Merlin exhibits reduced expression in PDAC patients $(42,53)$, is regulated by TGF $\beta$ (54), has been assigned a role in regulation of EMT in ARPE-19 cells (43), and in regulation of NHE1 in melanoma cells (45). We therefore hypothesized that Merlin depletion would impact TGF $\beta$-1-induced invasiveness and its regulation by NHE1 and NBCn1. Indeed, Merlin knockdown in itself robustly increased invasiveness, and under these conditions, knockdown of either NHE1 or NBCn1 decreased invasiveness, a tendency seen under both basal and TGF $\beta$-stimulated conditions. This indicates that the roles of NHE1 and NBCn1 may be particularly important in cancers with Merlin downregulation. It is well documented that the roles of $\mathrm{pH}$ regulatory transporters in invasion involve effects on focal adhesion strength and turnover, cytoskeletal dynamics, and matrix degradation, downstream of 
A

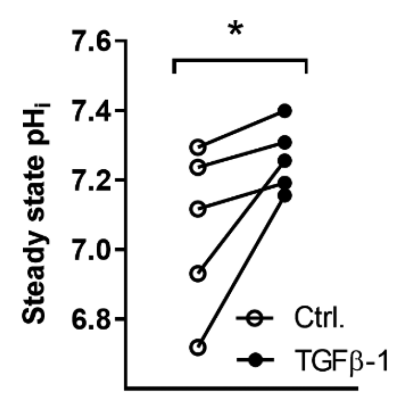

C

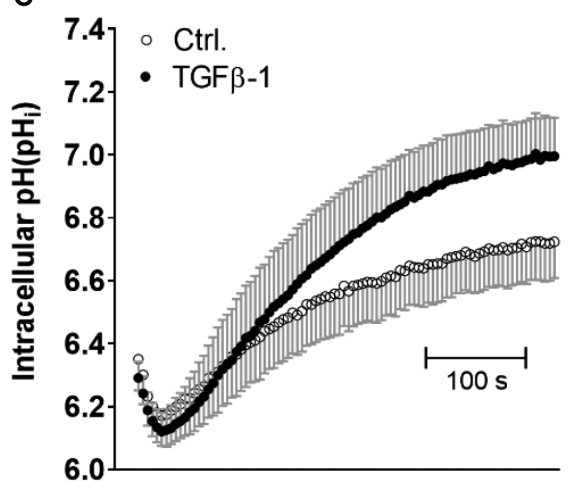

E

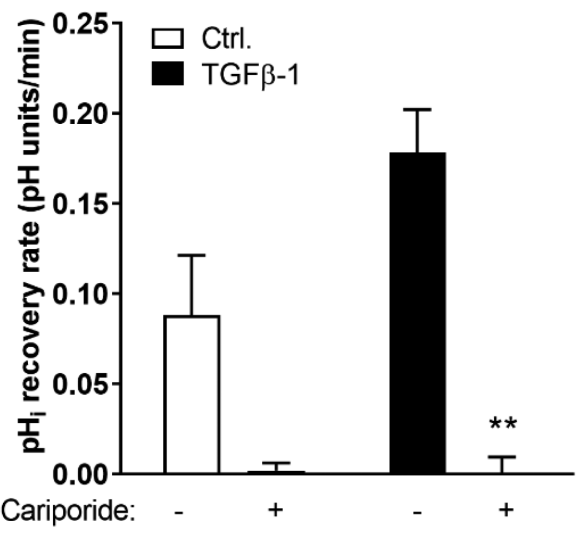

B

BxPC-3

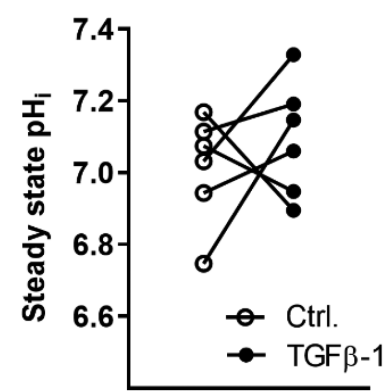

D

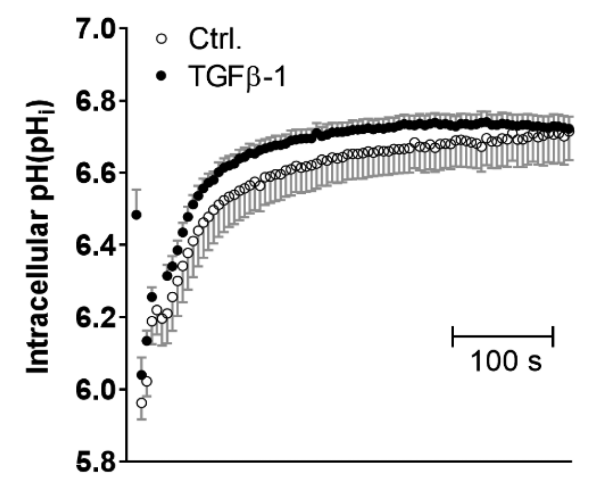

$\mathbf{F}$

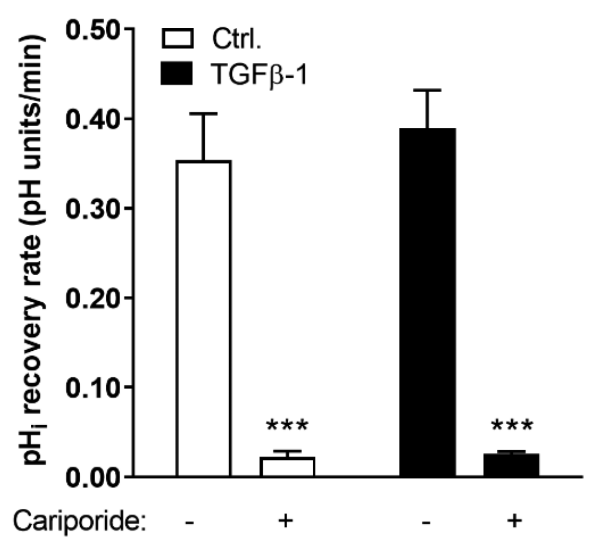

FIGURE 4 | TGF $\beta$ - 1 increases steady state $\mathrm{pH}_{\mathrm{i}}$ and $\mathrm{NHE} 1$-dependent acid extrusion in Panc-1 cells. Cells were treated $\pm 10 \mathrm{ng} / \mathrm{ml} \mathrm{TGF} \beta-1$ for $48 \mathrm{~h}$, and intracellular $\mathrm{pH}\left(\mathrm{pH}_{\mathrm{i}}\right)$ was monitored by real-time imaging analysis in Panc-1 (A,C,E) and BxPC-3 (B,D,F) cells after loading of cells with BCECF-AM. Experiments were conducted at $37^{\circ} \mathrm{C}$, and under $\mathrm{CO}_{2} / \mathrm{HCO}_{3}^{-}$buffered conditions. (A,B) Steady state $\mathrm{pH}_{\mathrm{i}}$ was increased by TGF $\beta-1$ in Panc- 1 but not in $\mathrm{BxPC}-3$ cells. The graphs show the $\mathrm{pH}$ paired control and TGF $\beta-1$ treated cells from each experiment. The mean $\mathrm{pH}_{\mathrm{i}}$ values were, for Panc- 1 cells, $7.06 \pm 0.105$ in control cells and $7.26 \pm 0.043$ after TGF $\beta-1$ treatment, and in BxPC-3 cells, $7.01 \pm 0.062$ in controls and $7.09 \pm 0.066$ after TGF $\beta-1$. Data are based on 5 (Panc-1) and 6 (BxPC-3) independent biological experiments for each condition. * significantly different, $p<0.05$, paired $t$-test. (C-F) The $\mathrm{pH}_{\mathrm{i}}$ recovery rate was determined as the initial rate of recovery after $\mathrm{NH}_{4} \mathrm{Cl}$-prepulse-induced intracellular acidification. Where indicated, cariporide $(10 \mu \mathrm{M})$ was present during the recovery phase to inhibit $\mathrm{NHE1}$. (C, $\left.\mathbf{D}\right)$ Representative traces with SD error bars, (E,F) means with S.E.M. error bars of 3-5 independent experiments per condition. ${ }^{\star *}$, ${ }^{\star * \star}$ Paired $t$-test, $p<0.01$ and 0.001 , respectively against corresponding conditions (Ctrl, TGF $\beta$ ) in absence of cariporide).

transporter-mediated changes in $\mathrm{pH}_{\mathrm{i}}$ and pericellular $\mathrm{pH}_{\mathrm{e}}(41)$. While the precise roles of the transporters in Panc- 1 cell invasion were not further studied here, this is supported by the increased $\mathrm{pH}_{\mathrm{i}}$ and acid extrusion capacity in TGF $\beta$-stimulated Panc- 1 cells also demonstrated here.
A limitation of this study is that we did not study the correlation of NHE1 and NBCn1 with EMT markers, TGF $\beta$ signaling pathway components, and Merlin expression in patient tumor tissue from primary pancreatic tumors and metastases. Future work should address such correlations to evaluate the 


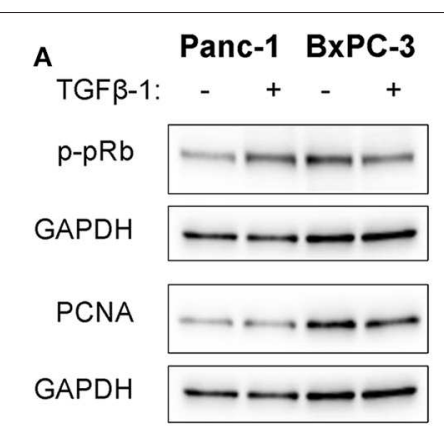

D

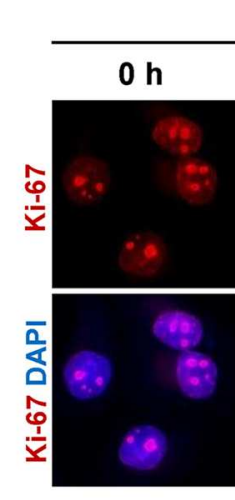

Panc-1

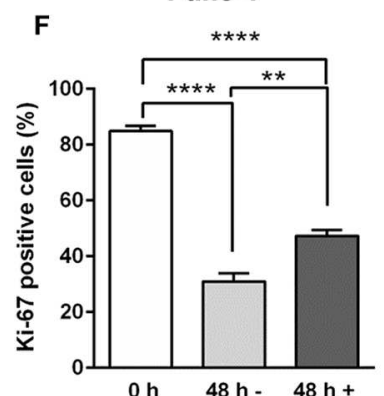

H

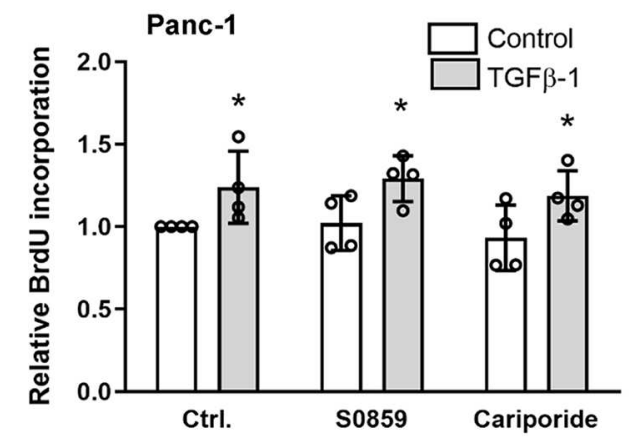

Panc-1
$48 \mathrm{~h} \quad 48 \mathrm{~h}(\mathrm{TGF} \beta-1)$
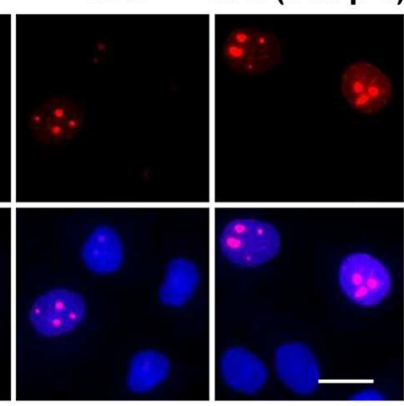

BXPC-3

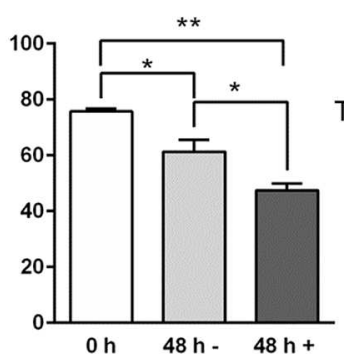

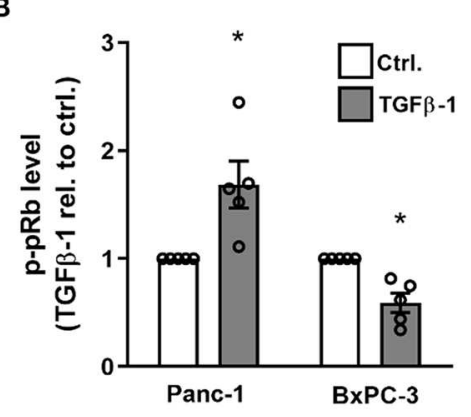

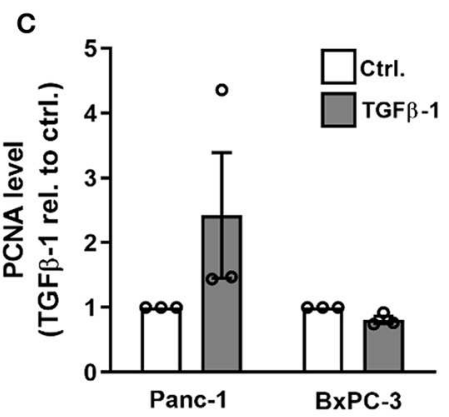

E

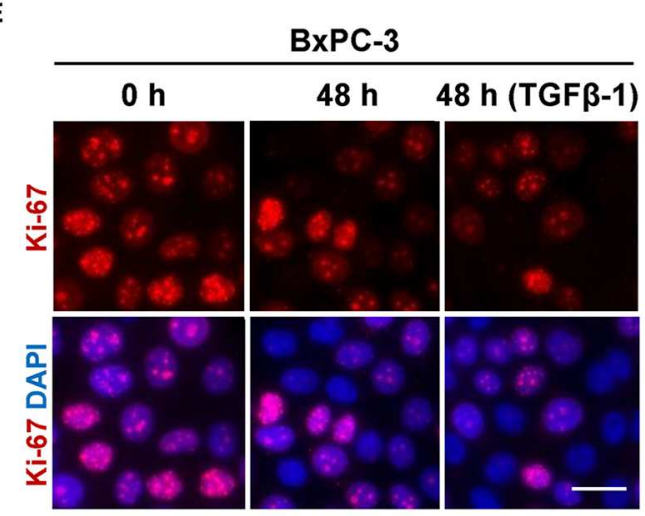

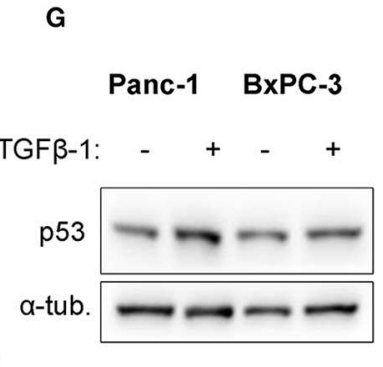

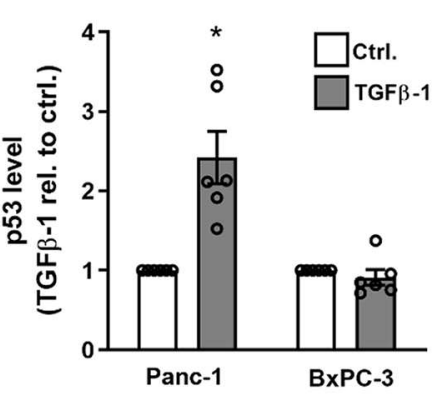

|

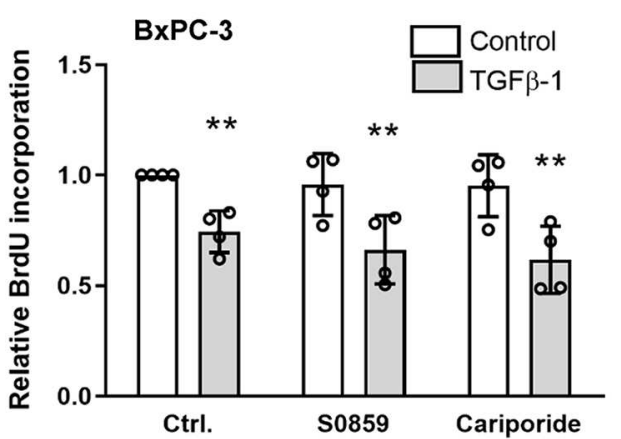

FIGURE 5 | TGF $\beta$-1 stimulates proliferation in Panc-1 cells, and inhibits it in BxPC-3 cells. (A) Panc-1 and BxPC-3 cells were serum starved for $24 \mathrm{~h}$, followed by $48 \mathrm{~h}$ growth with or without TGF $\beta-1$ as indicated. Cells were lysed and blotted for p-pRb and PCNA, using GAPDH as loading marker. (B,C) Relative p-pRB and PCNA levels from data as in (A). Data are normalized to ctrl. and shown as mean with S.E.M. error bars and individual data points. $n=3-5$ per condition. ${ }^{*} p<0.05$, paired, two-tailed $t$-test, against the level in non-TGF $\beta$ - 1 treated cells. (D,E) Immunofluorescence analysis of Ki- 67 after 0 or $48 \mathrm{~h}$ of serum starvation, the latter \pm TGF $\beta$ - 1 as shown. Ki-67 positive cells are quantified in (F). Data represent 3 independent experiments. (G) Panc- 1 and BxPC-3 cells were serum starved for $24 \mathrm{~h}$, grown for $48 \mathrm{~h}$ with or without TGF $\beta$, lysed and blotted for p53. $n=4$. $(\mathbf{H}, \mathbf{I})$ Proliferation of Panc-1 $\mathbf{( H )}$ and BxPC-3 $\mathbf{( I )}$ cells determined by BrdU incorporation, in absence or presence of NHE1 inhibitor cariporide $(10 \mu \mathrm{M})$ or NBC inhibitor S0859 $(10 \mu \mathrm{M}) . n=4$. Data are normalized to untreated ctrl. and shown as mean with S.E.M. error bars and individual data points. ${ }^{*} p<0.05$, ${ }^{* *} p<0.01$, and ${ }^{* * *} p<0.0001$, respectively. 


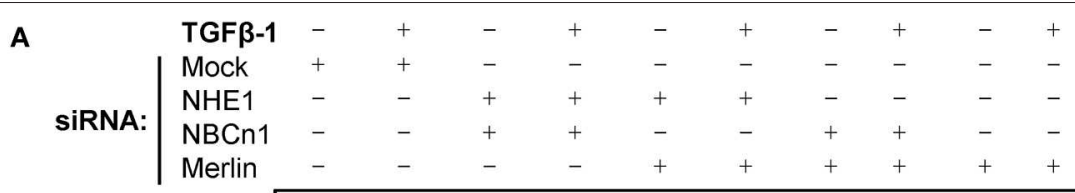
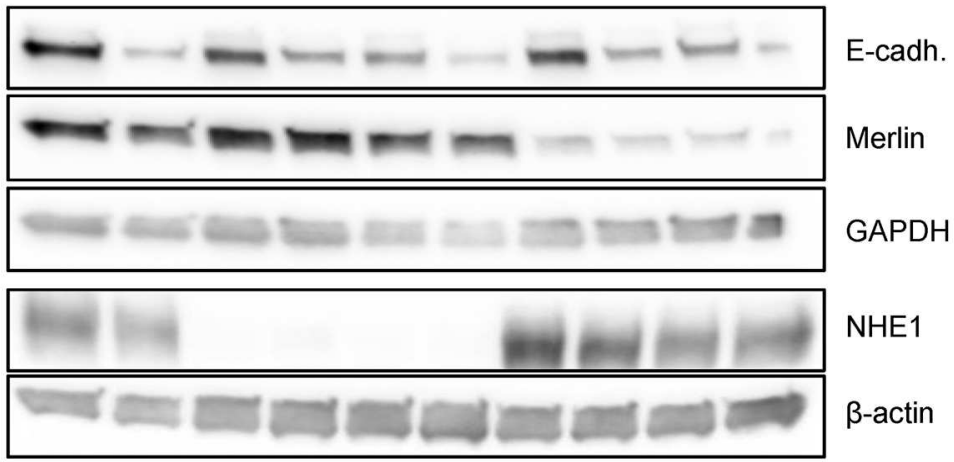

NHE1

$\beta$-actin

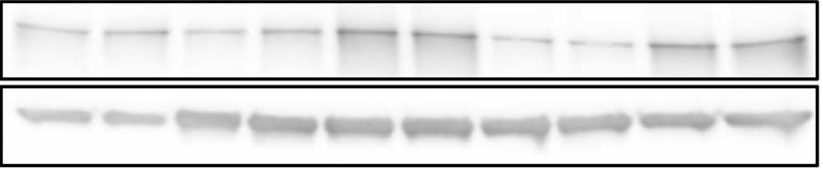

NBCn1

$\beta$-actin
B

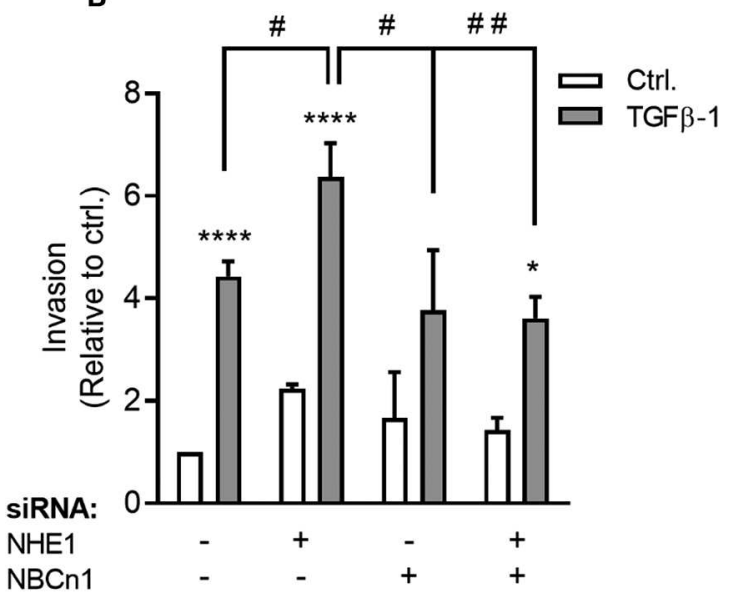

C

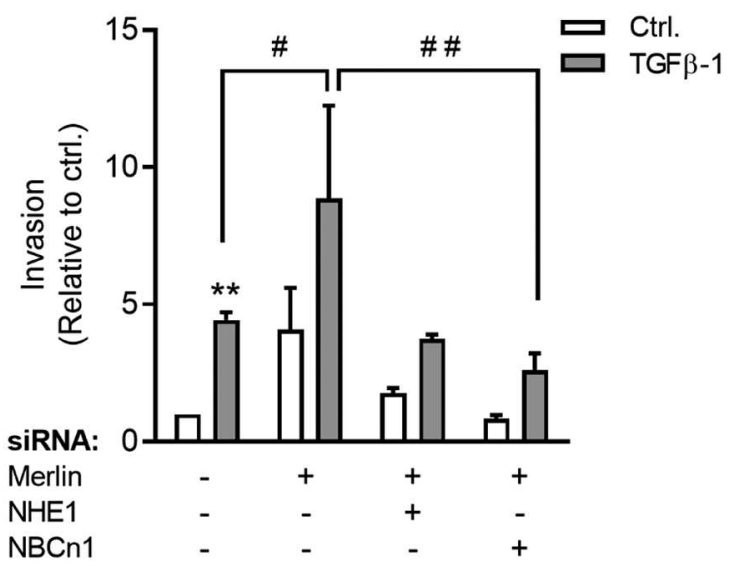

FIGURE 6 | Roles of NHE1, NBCn1, and Merlin in TGF $\beta$-induced invasiveness of Panc-1 cells. (A) Panc-1 cells were treated with siRNA against NHE1, NBCn1, and /or Merlin as indicated, starved for $48 \mathrm{~h}$, and treated or not with TGF $\beta-1$ for $48 \mathrm{~h}$, followed by Western blotting to assess protein expression levels. Data represent three independent experiments. (B) Panc-1 cells were treated with siRNA against NHE1 or NBCn1 as indicated, treated or not with TGF $\beta-1$ as above for $48 \mathrm{~h}$, and seeded at 50,000 cells/well in in serum-free medium in Matrigel-coated Boyden chambers. The lower chamber contained 10\% FBS. Twenty-two hours later, experiments were terminated and the number of invaded cells determined. (C) As (B), except including knockdown of merlin as indicated. $n=3-15$ independent experiments, each done in duplicate, per condition. $\left.{ }^{*},{ }^{\star \star},{ }^{\star \star \star \star}\right) p<0.05,0.01$, and 0.0001 , respectively, 2-way ANOVA, ctrl. vs. TGF $\beta ; \#, \# \# p<0.05,0.01$, respectively, 2-way ANOVA between the indicated conditions.

relevance of TGF $\beta$-mediated regulation of these transporters to invasiveness in patients.

In conclusion, we show here that NHE1 and NBCn1 expression and NHE-dependent acid extrusion are upregulated during TGF $\beta$-1-induced EMT of Panc-1 cells. NHE1 upregulation is SMAD4-dependent, and SMAD4-deficient BxPC-3 cells show no change in $\mathrm{pH}_{\mathrm{i}}$ regulation. The difference between Panc-1 and BxPC-3 cells is corroborated in opposite effects of TGF $\beta-1$ on cell proliferation, which is increased in Panc-1 and decreased in BxPC-3 cells by treatment with this ligand. Knockdown of Merlin strongly potentiates TGF/-1-induced Panc-1 cell invasiveness in a manner dependent on acid-extruding transporters. We suggest that these transporters are novel players in the events induced during TGF $\beta$-1-induced EMT in PDAC cells.

\section{DATA AVAILABILITY STATEMENT}

The datasets generated for this study are available on request to the corresponding author. 


\section{AUTHOR CONTRIBUTIONS}

SP, SC, and LP developed the concept. SP, SC, RM, and $\mathrm{KZ}$ designed the experiments. RM, PS, and $\mathrm{KZ}$ performed the experiments for Figures 2A-D, 3A-D,H-I, and RM the experiments for Figure 6 and Supplementary Figure 1. SP performed the experiments in Figure 4. Experiments in Figures 5A-G and Supplementary Figure 2 were performed by PS, and Figures $5 \mathbf{H}-\mathbf{I}$ by ML. Data analysis and figures were done by SP, RM, KZ, PS, and ML. RM and SP wrote the manuscript with comments and inputs from all co-authors. All authors have seen and approved the final version of the manuscript.

\section{FUNDING}

This work was supported by the Marie Curie Initial Training Network IonTraC (grant agreement no. 289648) and by the Hartmann Foundation. RM was supported by a PhD fellowship

\section{REFERENCES}

1. Rahib L, Smith BD, Aizenberg R, Rosenzweig AB, Fleshman JM, Matrisian LM. Projecting cancer incidence and deaths to 2030: the unexpected burden of thyroid, liver, and pancreas cancers in the United States. Cancer Res. (2014) 74:2913-21. doi: 10.1158/0008-5472.CAN-14-0155

2. Costello E, Greenhalf W, Neoptolemos JP. New biomarkers and targets in pancreatic cancer and their application to treatment. Nat Rev Gastroenterol Hepatol. (2012) 9:435-44. doi: 10.1038/nrgastro.2012.119

3. Pedersen SF, Novak I, Alves F, Schwab A, Pardo LA. Alternating pH landscapes shape epithelial cancer initiation and progression: focus on pancreatic cancer. Bioessays. (2017) 39:1600253. doi: 10.1002/bies.201600253

4. Bailey P, Chang DK, Nones K, Johns AL, Patch AM, Gingras MC, et al. Genomic analyses identify molecular subtypes of pancreatic cancer. Nature. (2016) 531:47-52. doi: 10.1038/nature16965

5. Jones S, Zhang X, Parsons DW, Lin JC, Leary RJ, Angenendt P, et al. Core signaling pathways in human pancreatic cancers revealed by global genomic analyses. Science. (2008) 321:1801-6. doi: 10.1126/science.1164368

6. David CJ, Massague J. Contextual determinants of TGFbeta action in development, immunity and cancer. Nat Rev Mol Cell Biol. (2018) 19:41935. doi: 10.1038/s41580-018-0007-0

7. Derynck R, Zhang YE. Smad-dependent and Smad-independent pathways in TGF-beta family signalling. Nature. (2003) 425:57784. doi: $10.1038 /$ nature 02006

8. Ikushima H, Miyazono K. TGFbeta signalling: a complex web in cancer progression. Nat Rev Cancer. (2010) 10:415-24. doi: 10.1038/nrc2853

9. Gaspar NJ, Li L, Kapoun AM, Medicherla S, Reddy M, Li G, et al. Inhibition of transforming growth factor beta signaling reduces pancreatic adenocarcinoma growth and invasiveness. Mol Pharmacol. (2007) 72:15261. doi: 10.1124/mol.106.029025

10. Medicherla S, Li L, Ma JY, Kapoun AM, Gaspar NJ, Liu YW, et al. Antitumor activity of TGF-beta inhibitor is dependent on the microenvironment. Anticancer Res. (2007) 27:4149-57.

11. Whittle MC, Izeradjene K, Rani PG, Feng L, Carlson MA, DelGiorno KE, et al. RUNX3 controls a metastatic switch in pancreatic ductal adenocarcinoma. Cell. (2015) 161:1345-60. doi: 10.1016/j.cell.2015.04.048

12. Ijichi H, Chytil A, Gorska AE, Aakre ME, Fujitani Y, Fujitani S, et al. Aggressive pancreatic ductal adenocarcinoma in mice caused by pancreas-specific blockade of transforming growth factor-beta signaling in cooperation with active Kras expression. Genes Dev. (2006) 20:314760. doi: 10.1101/gad.1475506 from the Government of India and the Department of Biology, University of Copenhagen.

\section{ACKNOWLEDGMENTS}

HPDE cells were a kind gift from Dr. Ming-Sound Tsao, Ontario Cancer Institute, Toronto, Canada $(27,28)$, and antibody against NBCn1 was a kind gift from Prof. J. Praetorius, Aarhus University. We gratefully acknowledge S. C. Kong for performing parts of the experiments for Figure 1, and the excellent technical assistance from K. F. Mark.

\section{SUPPLEMENTARY MATERIAL}

The Supplementary Material for this article can be found online at: https://www.frontiersin.org/articles/10.3389/fonc. 2020.00687/full\#supplementary-material

13. David CJ, Huang YH, Chen M, Su J, Zou Y, Bardeesy N, et al. TGFbeta tumor suppression through a lethal EMT. Cell. (2016) 164:101530. doi: 10.1016/j.cell.2016.01.009

14. Vogelmann R, Nguyen-tat MD, Giehl K, Adler G, Wedlich D, Menke A. TGFbeta-induced downregulation of E-cadherin-based cellcell adhesion depends on PI3-kinase and PTEN. J Cell Sci. (2005) 118:4901-12. doi: 10.1242/jcs.02594

15. Kabashima A, Higuchi H, Takaishi H, Matsuzaki Y, Suzuki S, Izumiya M, et al. Side population of pancreatic cancer cells predominates in TGF-betamediated epithelial to mesenchymal transition and invasion. Int J Cancer. (2009) 124:2771-9. doi: 10.1002/ijc.24349

16. Zheng X, Carstens JL, Kim J, Scheible M, Kaye J, Sugimoto H, et al. Epithelial-to-mesenchymal transition is dispensable for metastasis but induces chemoresistance in pancreatic cancer. Nature. (2015) 527:52530. doi: 10.1038/nature16064

17. Bardeesy N, Cheng KH, Berger JH, Chu GC, Pahler J, Olson P, et al. Smad4 is dispensable for normal pancreas development yet critical in progression and tumor biology of pancreas cancer. Genes Dev. (2006) 20:3130-46. doi: 10.1101/gad.1478706

18. Lamouille S, Derynck R. ell size and invasion in TGF-beta-induced epithelial to mesenchymal transition is regulated by activation of the mTOR pathway. $J$ Cell Biol. (2007) 178:437-51. doi: 10.1083/jcb.200611146

19. Boedtkjer E, Pedersen SF. The acidic tumor microenvironment as a driver of cancer. Ann Rev Physiol. (2020) 82:10326. doi: 10.1146/annurev-physiol-021119-034627

20. Webb BA, Chimenti M, Jacobson MP, Barber DL. Dysregulated pH: a perfect storm for cancer progression. Nat Rev Cancer. (2011) 11:6717. doi: $10.1038 / \mathrm{nrc} 3110$

21. Andersen AP, Samsøe-Petersen J, Oernbo EK, Boedtkjer E, Moreira JM, Kveiborg M, et al. The net acid extruders NHE1, NBCn1 and MCT4 promote mammary tumor growth through distinct but overlapping mechanisms. Int J Cancer. (2018) 142:2529-42. doi: 10.1002/ijc.31276

22. Lee S, Axelsen TV, Andersen AP, Vahl P, Pedersen SF, Boedtkjer E. Disrupting $\mathrm{Na}^{+}, \mathrm{HCO}_{3}^{-}$-cotransporter $\mathrm{NBCn} 1$ (Slc4a7) delays murine breast cancer development. Oncogene. (2016) 35:2112-22. doi: 10.1038/onc.2015.273

23. Parks SK, Pouyssegur J. The $\mathrm{Na}^{+}, \mathrm{HCO}_{3}^{-}$-Co-Transporter SLC4A4 plays a role in growth and migration of colon and breast cancer cells. J Cell Physiol. (2015) 230:1954-63. doi: 10.1002/jcp.24930

24. Amith SR, Wilkinson JM, Baksh S, Fliegel L. The $\mathrm{Na}^{+} / \mathrm{H}^{+}$exchanger (NHE1) as a novel co-adjuvant target in paclitaxel therapy of triple-negative breast cancer cells. Oncotarget. (2015) 6:1262-75. doi: 10.18632/oncotarget.2860 
25. Schwab A, Fabian A, Hanley PJ, Stock C. Role of ion channels and transporters in cell migration. Physiol Rev. (2012) 92:1865913. doi: 10.1152/physrev.00018.2011

26. Karydis A, Jimenez-Vidal M, Denker SP, Barber DL. Mislocalized scaffolding by the Na-H exchanger NHE1 dominantly inhibits fibronectin production and TGF-beta activation. Mol Biol Cell. (2009) 20:2327-36. doi: 10.1091/mbc.e08-08-0842

27. Furukawa T, Duguid WP, Rosenberg L, Viallet J, Galloway DA, Tsao MS. Longterm culture and immortalization of epithelial cells from normal adult human pancreatic ducts transfected by the E6E7 gene of human papilloma virus 16 . Am J Pathol. (1996) 148:1763-70.

28. Ouyang H, Mou LJ, Luk C, Liu N, Karaskova J, Squire J, et al. Immortal human pancreatic duct epithelial cell lines with near normal genotype and phenotype. Am J Pathol. (2000) 157:1623-31. doi: 10.1016/S0002-9440(10)64800-6

29. Kong SC, Gianuzzo A, Novak I, Pedersen SF. Acid-base transport in pancreatic cancer: molecular mechanisms and clinical potential. Biochem Cell Biol. (2014) 92:449-59. doi: 10.1139/bcb-2014-0078

30. Lauritzen G, Jensen MB, Boedtkjer E, Dybboe R, Aalkjær C, Nylandsted J, et al. NBCn1 and NHE1 expression and activity in DeltaNErbB2 receptor-expressing MCF-7 breast cancer cells: contributions to $\mathrm{pHi}$ regulation and chemotherapy resistance. Exp Cell Res. (2010) 316:253853. doi: 10.1016/j.yexcr.2010.06.005

31. Boedtkjer E, Moreira JM, Mele M, Vahl P, Wielenga VT, Christiansen PM, et al. Contribution of $\mathrm{Na}^{+}, \mathrm{HCO}_{3}^{-}$-cotransport to cellular $\mathrm{pH}$ control in human breast cancer: a role for the breast cancer susceptibility locus NBCn1 (SLC4A7) 4. Int J Cancer. (2013) 132:1288-99. doi: 10.1002/ijc.27782

32. Cardone RA, Greco MR, Zeeberg K, Zaccagnino A, Saccomano M, Bellizzi A, et al. A novel NHE1-centered signaling cassette drives epidermal growth factor receptor-dependent pancreatic tumor metastasis and is a target for combination therapy. Neoplasia. (2015) 17:15566. doi: 10.1016/j.neo.2014.12.003

33. Gorbatenko A, Olesen CW, Boedtkjer E, Pedersen SF. Regulation and roles of bicarbonate transporters in cancer. Front Physiol. (2014) 5:130. doi: 10.3389/fphys.2014.00130

34. Deer EL, González-Hernández J, Coursen JD, Shea JE, Ngatia J, Scaife CL, et al. Phenotype and genotype of pancreatic cancer cell lines. Pancreas. (2010) 39:425-435. doi: 10.1097/MPA.0b013e3181c15963

35. Takano S, Kanai F, Jazag A, Ijichi H, Yao J, Ogawa H, et al. Smad4 is essential for down-regulation of E-cadherin induced by TGF-beta in pancreatic cancer cell line PANC-1. J Biochem. (2007) 141:345-51. doi: 10.1093/jb/mvm039

36. Boron WF. Regulation of intracellular pH. Adv Physiol Educ. (2004) 28:16079. doi: 10.1152/advan.00045.2004

37. Pedersen SF, Counillon L. The SLC9A-C mammalian $\mathrm{Na}^{+} / \mathrm{H}^{+}$exchanger family: Molecules, mechanisms and physiology. Physiol Rev. (2019) 99:2015113. doi: 10.1152/physrev.00028.2018

38. Boedtkjer E, Bunch L, Pedersen SF. Physiology, pharmacology and pathophysiology of the $\mathrm{pH}$ regulatory transport proteins NHE1 and NBCn1: similarities, differences, and implications for cancer therapy 1. Curr Pharm Des. (2012) 18:1345-71. doi: 10.2174/138161212799504830

39. Schneider L, Stock CM, Dieterich P, Jensen BH, Pedersen LB, Satir P, et al. The $\mathrm{Na}^{+} / \mathrm{H}^{+}$exchanger NHE1 is required for directional migration stimulated via PDGFR-alpha in the primary cilium. J Cell Biol. (2009) 185:163-76. doi: 10.1083/jcb.200806019

40. Busco G, Cardone RA, Greco MR, Bellizzi A, Colella M, Antelmi E, et al. NHE1 promotes invadopodial ECM proteolysis through acidification of the peri-invadopodial space. FASEB J. (2010) 24:3903-15. doi: 10.1096/fj.09-149518

41. Stock C, Pedersen SF. Roles of $\mathrm{pH}$ and the $\mathrm{Na}^{+} / \mathrm{H}^{+}$exchanger NHE1 in cancer: From cell biology and animal models to an emerging translational perspective? Semin Cancer Biol. (2017) 43:5-16. doi: 10.1016/j.semcancer.2016.12.001
42. Quan M, Cui J, Xia T, Jia Z, Xie D, Wei D, et al. Merlin/NF2 suppresses pancreatic tumor growth and metastasis by attenuating the FOXM1-mediated Wnt/beta-catenin signaling. Cancer Res. (2015) 75:477889. doi: 10.1158/0008-5472.CAN-14-1952

43. Takahashi E, Haga A, Tanihara H. Merlin regulates epithelial-tomesenchymal transition of ARPE-19 cells via TAK1-p38MAPK-mediated activation. Invest Ophthalmol Vis Sci. (2015) 56:2449-58. doi: 10.1167/iovs. 14- 16300

44. Petrilli AM, Fernandez-Valle C. Role of Merlin/NF2 inactivation in tumor biology. Oncogene. (2016) 35:537-48. doi: 10.1038/onc.2015.125

45. Frontzek F, Nitzlaff S, Horstmann M, Schwab A, Stock C. Functional interdependence of NHE1 and merlin in human melanoma cells. Biochem Cell Biol. (2014) 92:530-40. doi: 10.1139/bcb-2014-0041

46. Feig C, Gopinathan A, Neesse A, Chan DS, Cook N, Tuveson DA. The pancreas cancer microenvironment 1. Clin Cancer Res. (2012) 18:426676. doi: 10.1158/1078-0432.CCR-11-3114

47. Vincent T, Neve EP, Johnson JR, Kukalev A, Rojo F, Albanell J, et al. A SNAIL1-SMAD3/4 transcriptional repressor complex promotes TGF-beta mediated epithelial-mesenchymal transition. Nat Cell Biol. (2009) 11:94350. doi: 10.1038/ncb1905

48. Dykes SS, Gao C, Songock WK, Bigelow RL, Woude GV, Bodily JM, et al. Zinc finger E-box binding homeobox-1 (Zeb1) drives anterograde lysosome trafficking and tumor cell invasion via upregulation of $\mathrm{Na}^{+} / \mathrm{H}^{+}$Exchanger-1 (NHE1). Mol Carcinog. (2016) 56:722-34. doi: 10.1002/mc.22528

49. Scholz W, Albus U, Counillon L, Gögelein H, Lang HJ, Linz W, et al. Protective effects of HOE642, a selective sodium-hydrogen exchange subtype 1 inhibitor, on cardiac ischaemia and reperfusion. Cardiovasc Res. (1995) 29:260-8. doi: 10.1016/S0008-6363(96)88579-8

50. Benedetti A, Di Sario A, Baroni GS, Jezequel AM. Transforming growth factor beta 1 increases the number of apoptotic bodies and decreases intracellular $\mathrm{pH}$ in isolated periportal and perivenular rat hepatocytes. Hepatology. (1995) 22:1488-98. doi: 10.1002/hep.1840220524

51. Commisso C, Davidson SM, Soydaner-Azeloglu RG, Parker SJ, Kamphorst JJ, Hackett S, et al. Macropinocytosis of protein is an amino acid supply route in Ras-transformed cells. Nature. (2013) 497:633-7. doi: 10.1038/nature 12138

52. Lauritzen G, Stock CM, Lemaire J, Lund SF, Jensen MF, Damsgaard B, et al. The $\mathrm{Na}^{+} / \mathrm{H}^{+}$exchanger NHE1, but not the $\mathrm{Na}+, \mathrm{HCO} 3(-)$ cotransporter NBCn1, regulates motility of MCF7 breast cancer cells expressing constitutively active ErbB2 1. Cancer Lett. (2012) 317:1723. doi: 10.1016/j.canlet.2011.11.023

53. Zhou J, Feng Y, Tao K, Su Z, Yu X, Zheng J, et al. The expression and phosphorylation of ezrin and merlin in human pancreatic cancer. Int J Oncol. (2014) 44:2059-67. doi: 10.3892/ijo.2014.2381

54. Takahashi E, Nagano O, Ishimoto T, Yae T, Suzuki Y, Shinoda T, et al. Tumor necrosis factor-alpha regulates transforming growth factor-beta-dependent epithelial-mesenchymal transition by promoting hyaluronan-CD44-moesin interaction. J Biol Chem. (2010) 285:4060-73. doi: 10.1074/jbc.M109. 056523

Conflict of Interest: The authors declare that the research was conducted in the absence of any commercial or financial relationships that could be construed as a potential conflict of interest.

Copyright (c) 2020 Malinda, Zeeberg, Sharku, Ludwig, Pedersen, Christensen and Pedersen. This is an open-access article distributed under the terms of the Creative Commons Attribution License (CC BY). The use, distribution or reproduction in other forums is permitted, provided the original author(s) and the copyright owner(s) are credited and that the original publication in this journal is cited, in accordance with accepted academic practice. No use, distribution or reproduction is permitted which does not comply with these terms. 